\title{
A CREATIVE MILIEU AND THE ROLE OF GEOGRAPHY IN STUDYING THE COMPETITIVENESS OF CITIES: THE CASE OF LJUBLJANA
}

USTVARJALNO OKOLJE IN VLOGA GEOGRAFIJE PRI PROUCEVANJU KONKURENCNOSTI MEST: PRIMER LJUBLJANE

Marjan Ravbar, David Bole, Janez Nared

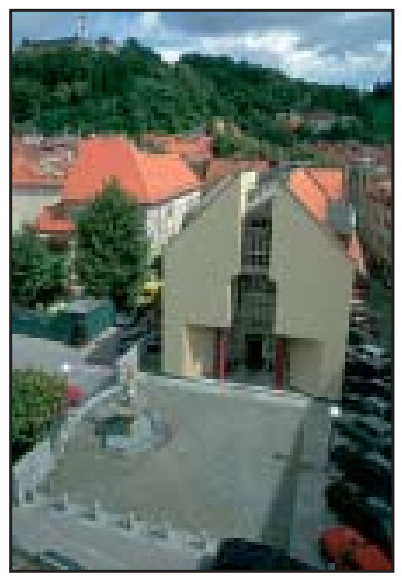

Knowledge - the Motor of Development (photography: Milan Orožen Adamič). Znanje - motor razvoja (fotografija: Milan Orožen Adamič).

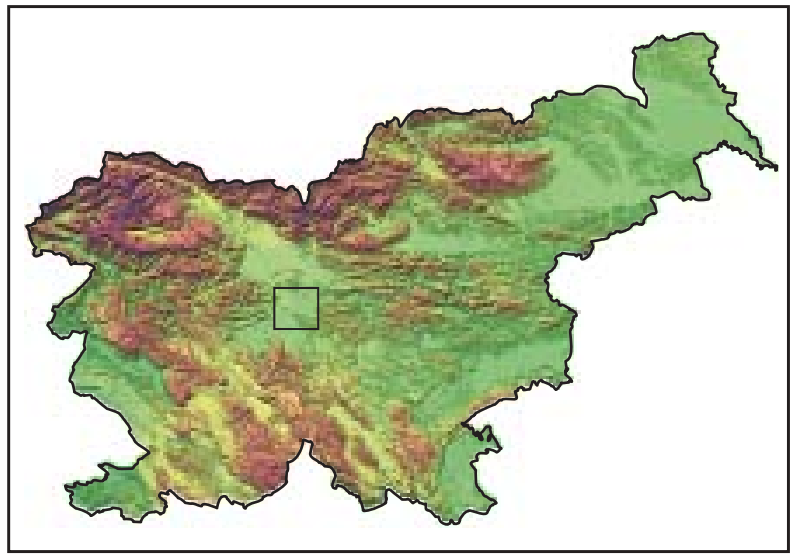




\section{A creative milieu and the role of geography in studying the competitiveness of cities: the case of Ljubljana}

UDC: $911.375(497.4$ Ljubljana)

COBISS: 1.01

ABSTRACT: The article is composed of two parts. The first is based on theoretical geographical-developmental factors of balanced competitiveness of cities (regions) in conditions of globalization and the emphasized role of a creative milieu as fundamental development impulses. The second one explores the importance of Ljubljana and its role in the system of innovative urban centers in contrast to the metropolis agglomerations in the wider surroundings employing empirical findings. We support its position using the geographical dimensions of innovative dynamics as the fundamental development generator for the entire national urban system and evaluate its developmental research potential as well as investment, economic, and population capacities from the viewpoint of the opportunities offered by its central position and function as a capital city.

KEYWORDS: economic geography, creative milieu, learning regions, balanced competitiveness, network of cities, clustering, Ljubljana, Ljubljana city region.

The article was submitted for publication on October 17, 2005.

\section{AUTHORS:}

Marjan Ravbar, Ph. D

Anton Melik Geographical Institute

Scientific Research Centre of the Slovenian Academy of Sciences and Arts

Gosposka ulica 13, SI - 1000 Ljubljana, Slovenia

E-mail: marjan.ravbar@zrc-sazu.si

David Bole, B. Sc.

Anton Melik Geographical Institute

Scientific Research Centre of the Slovenian Academy of Sciences and Arts

Gosposka ulica 13, SI - 1000 Ljubljana, Slovenia

E-mail: david.bole@zrc-sazu.si

Janez Nared, B. Sc.

Anton Melik Geographical Institute

Scientific Research Centre of the Slovenian Academy of Sciences and Arts

Gosposka ulica 13, SI - 1000 Ljubljana, Slovenia

E-mail: janez.nared@zrc-sazu.si

\section{Contents}

1 Introduction 9

2 Learning regions/cities - the role of clustering (networking) in the geographical transformation of society 9

3 Characteristics of knowledge-based regions 11

4 Interaction of research, cooperation, and competition of cities/regions the case of Ljubljana $\quad 13$

5 Conclusion 19

6 References 21 


\section{Introduction}

This article is an attempt to identify some geographical-developmental factors for the competitiveness of cities/regions in conditions of globalization and the emphasized role of a creative milieu as fundamental modern development impulses. We emphasize the spatial influences and consequences of balanced competitiveness, in particular the »new tertiarization of cities «, global operations, the geographical dimensions of technological development, the distribution of modern investment activities as developmental promoters of competitiveness, local factors, deregulation, the transformation of infrastructure systems, the intertwinement and linking between networks of cities, clustering. Changing conditions transform the functional division of urban facilities as well as the social infrastructure that is of vital importance for the existence of a creative milieu, especially relative to economic links and the promotion of research and complementary activities. The article is linked with studies of the influences of the creative milieu on changes in spatial-developmental structures of cities and their areas of influence.

Too little attention has been devoted in Slovene geographical literature to the transformation of cities due to the influences of the creative milieu, one of the important elements in the structural changes of a region. We will try to answer some of the questions through a critical research survey and in the framework of the available space, and simultaneously open new dimensions in economic geography as a challenge for continuation of in-depth discussions.

\section{Learning regions/cities - the role of clustering (networking) in the geographical transformation of society}

Economists, sociologists, and regional planners have long been engaged in studying the intricate contents and factors of innovation-driven development. Less so (Slovene) geographers, even though this is a rich area for study linked with modern structural changes in regions. Classical studies, which previously focused on the importance of regional facilities and presented the changes in spatial and economic structures, the offer of service activities, the presence of highly productive research activities, traffic connections, the quality of the living environment, etc., are being replaced by new aspects of evaluating relationships within geographically rounded regional communities. For this reason, the concept creative milieu is most frequently used in numerous discussions along with various complementary concepts (learning regions, industrial districts, innovative clusters) that emphasize the geographical dimensions of the linkage of science and technology centers with other economic networks and the close institutional and personal involvement in the social environment, which has important spatial implications on the regional level. In a way, this is a new view to which the original but modern interpretation of contents in regional geography is adapted.

Modern development policies require geographical studies to produce comprehensive assessments of homogenous regions and an evaluation of the consequences of central (key) problems of a region on the basis of natural conditions and consideration of the interests of the indigenous population. In the social and economic spheres, the training and education structure plays a decisive role, increasing the possibility of inclusion in innovative economic currents since developmental identity and sociocultural creativity defined »from the inside « are undoubtedly the strongest arguments for the (trans)formation of existing developmental disparities. With the appropriate education structure of the population, a creative milieu is formed that as a rule forms spatially closed communities where administrative borders are of lesser importance or do not represent any special »recognizable« criteria but rather are homogenous relative to their ability to act and to adapt. On the basis of such studies, it is possible to develop a suitable development policy with the help of autonomous financial decisions on the regional level.

Learning cities/regions are best described by specific processes that occur within inside their economies, labour markets, and technological progress. All these factors open possibilities for better political, cultural, social, and organizational progress in the city/region (Konstadakopulus and Christopoulus 2004). Many associate learning cities and a creative milieu with global competitiveness. Cities are no longer self-sufficient and 
are, like it or not, involved in the global economy. They are also no longer immune to wider social and political changes in the world. The strategic national $\leftrightarrow$ global economic link no longer holds since it is becoming ever clearer that the regional level linked with the decentralization of functions is gaining importance. This means that cities and strategic city regions are actually principal actors in the global economy, and it is up to city administrations to decide whether they will take advantage of the situation since globalization brings with positive as well as negative changes (Sassen 2002).

Here, the question arises whether there exists a universal model of directed development that will create conditions for the formation of a learning region or a creative milieu. The answer is multi-layered: innovativeness can be a consequence of planned development of knowledge and accumulation of other means, but at the same time it depends on factors that we find difficult to influence and that are »exceptional« for each geographical environment. A precondition for the development of innovativeness in a region is competition between economic branches, which stimulates technological development and learning, and links (synergy) between companies. A learning region occurs when economic, geographical, and sociocultural factors in a particular region are such as to stimulate technological progress, create knowledge, and thus try to create suitable conditions for economic progress.

In a modern economy, technological and institutional learning are acknowledged as the most important resources and are understood as a process by which individuals, organizations, and society as a whole invest in knowledge and innovativeness. The latter is formed on the basis of numerous institutional routines and is entirely socially conditioned. Innovativeness in economic institutions means the repetition of routines, habits, or patterns of conduct that contain concealed knowledge, usually in the form of various skills or »know-how «. Regions that combine social cohesion with principles of innovativeness and are simultaneously open to the rest of the world have better conditions for learning because they gather and identify new trends and new developments on the global level.

According to the analogy of physical and human capital, we can denote the ability to learn and innovativeness as »social capital « (Morgan 1997). Social capital refers to the factors of social organization and norms that transform investments in physical and human capital and their upgrading. Social capital is increasingly understood as a vital component for successful economic development. There are attempts to identify the successfulness of cities/regions with various characteristics presumed typical of learning regions. Among these, the following in particular dominate:

- degree of exploitation of local human resources and high mobility of the labour force;

- economic specialization of a region;

- strong innovative contacts within a region;

- high degree of synergy among local companies;

- collective learning process;

- recurring innovation processes and patenting of new discoveries;

- strong collective spirit and emphasized coordination of developmental activities;

- strong local and regional identity;

- strong links with the »outside world«.

Another important characteristic of learning regions is their connectedness - not only on the entrepreneurial level (between companies) but also on the regional level (between cities). Some call this process that benefits all its participants »networking«. A familiar initiative of this kind called »Core Cities" exists among English cities and includes Birmingham, Bristol, Leeds, Liverpool, Manchester, Newcastle, Nottingham, and Sheffield (Internet 1). This initiative also has an institutionalized form with the participation of city authorities, development agencies, and government ministries. Here, concrete action plans are adopted oriented toward the creation of a competitive region on a world scale, the so-called ideopolis, a concept of the Core Cities organization designating a region whose key elements include a university, an airport, the creation of new ideas, intellectual capital, and entrepreneurial self-confidence. With an educated labour force, technological development, and business competitiveness, a region is formed that attracts strategic investors and creates a self-sustaining cycle of economic growth and investment in science and education. 
The spatial concentration of companies from related fields is a general sign of successful economic development. Such clustering has its roots in the period of the mature phase of the industrial revolution when Ford-inspired associations, highly integrated for the conditions of the time, developed linking processes to the optimal extent possible. Linking processes of clustering in industry were later followed by similar activities of the financial sector, company-oriented service activities, and »cultural « production. In the 1980's, researchers from various unrelated areas, including economic geographers and regional economists became intensively engaged in studies of economic linking processes (Scott 2000). In recent years, the knowledge of various professions and their theoretic and empirical research findings have cross-pollinated, and the study of clustering (»clusterization «) has been recognized as an established branch of modern economic geography. The common denominator is the study of the "systemization « of the character of clustering as a specific complex of links in production and institutional relationships as an instrument in the chain of the creation of added value. We understand »clustering « as the linkage of production, service, and distribution of enterprises that participate in the production and sale of a certain product or family of products or service activities (Krätke, Scheuplein 2001). The chain of the creation of added value is known in variously occurring elements/functions among a multitude of companies that compose more or less complex models of division of labour.

From the beginning of Marshall's work on location choice and industrial districts, the idea of clusters has never had such important significance as in the past decade, a consequence of the desire of companies to increase their competitiveness and the desire of governments to exploit new sources of economic growth. It is precisely in geographically concentrated networks or clusters that the greatest regional added value and employment growth is realized, and therefore many are convinced that membership in clusters and networks among companies presents the fundamental means for stimulating the productivity and competitiveness of companies (Bröcker et al. 2003).

\section{Characteristics of knowledge-based regions}

The spatial concentration of companies and their reciprocal links increases the innovative ability of the milieu since inter-company networks become very significant in competitive conditions and a globalized economy. We can describe such a network as a collective activity of actors who have the same or similar goals, are not connected in a hierarchical system, and work on the basis of trust. Enterprises cooperate in a network of companies because they expect the formal or informal exchange of various content to bring material or non-material profit to the network as a whole or to individual companies. Here, they are subject to joint cooperation as well as mutual competition (Bergman 2003). Clusters unite groups of reciprocally linked companies and institutions that are important for the production of a certain group of products. Such clusters offer their members competitive advantages since production and process innovations can develop with rivalry and competition among local companies and spatial proximity, as well as the growth of productivity factors (Jarke et al. 2003). At the same time, it is necessary that the network be closely engaged in the sociocultural environment of the region, while its information tentacles can be very widely extended to allow the rapid development of information technologies.

It is more characteristic for innovation to be linked to high-tech innovative regional clusters than with footloose multinational corporations, which increases the importance of geographical proximity and regional agglomerations (Audretsch 2003). However, not just spatial proximity is important for clusters, but socioeconomic factors are also of central significance. Economic functioning is closely connected with social functioning where social capital is extremely important (Jarke et al. 2003). Here, city management must focus on establishing levers that will stimulate cooperation among companies, organizations, and public institutions and thus establish a framework for solving common problems and strengthening common learning processes (Diez 2001). According to the principles of endogenous development, the region is the key center for learning and the creation of knowledge in the period of globalization and science-intensive capitalism and is therefore the principal source of innovation and economic growth (Diez and Esteban 2000). 
If the innovation network is simultaneously part of the regional environment, we can talk about a creative milieu (Chancen 1996). This is based on non-market links between companies that encompass local knowledge and inter-personal contacts, formal and informal networks, the quality of local and regional institutions and their close links, and the long-term habits and norms that have secured specific advantages and profits for the companies and the region. Competitiveness is focused on social capital, the cultural context, norms, and values that can stimulate mutual understanding and strengthen trust between actors in the regional economy (Diez and Esteban 2000). In a creative milieu, it is of primary importance that partners preserve their independence and draw impulses for faster development and the development of new innovations and technologies from their linkage. Networks are thus based on non-material elements such as trust, latent knowledge, and a common awareness of values - in this way, positive effects of the milieu can occur, including reduced uncertainty in decision-making and effects of the common learning process that can lead to the development of specific regional know-how (Maier and Obermaier 1999). It is typical for creative milieus to occur in areas of population and economic agglomeration since they are closely dependent on a critical mass of »researchers « comprising about $10 \%$ of the population. Thus the presence of a university or higher education institutions is very desirable. The importance of higher education and research organizations has increased greatly. In the framework of innovation competitiveness, a very important role is played by innovation potential, from which growth impulses for further regional development originate. Higher education institutions increase innovation potential and heighten human capital and thus the advantage of a particular area in the regional competition. Higher education institutions are therefore incubators of knowledge and motivators of development at the same time (Heeb 2003). The task of higher education institutions must also be to inspire the entrepreneurial spirit of their graduates since experience so far indicates that only a small proportion of graduates decide to take an independent entrepreneurial path immediately after graduation while the majority only decide on an independent path eight to fifteen years later when they have acquired some experience (Jarke et al. 2003).

A high potential for growth and support for such companies from local scientific or educational institutes or scientific-industrial network connected with them are of key importance for the successful establishment of companies that are highly technically oriented. This network reduces the need for capital, which in many cases allows establishment of a company at all. The network also enables the continuing growth of these companies and reduces existing risks. Thus, two basic obstacles to the foundation of new companies, capital and marketing, are reduced because the network can temporarily replace them both (Burkhardt et al. 2003). In the 1990's, innovation and technology were recognized as a saving strategy because they helped to shorten production cycles, enabled intensive interaction between science, technology, and business, and provided an answer to the increasing complexity of technologies and the increasing competition due to internationalization and globalization. Today, innovative regions must look for new technologies and know-how and again create new market offers by developing specific solutions (Gerhardter and Gruber 2001).

However, we cannot regard creative milieus merely as innovative networks oriented toward technology, but more in the sense of the capability of regional actors to establish connections with research institutions for the sake of developing existing regional potential (Maier and Obermaier 1999). Thus, endogeny can mean the capability of regional actors to independently adopt external information (know-how, technologies, organizational structures) and incorporate it into their own regional system. Here, not only individual initiatives but also the coordinated operation of all development factors play a decisive role in the success of regional development (Gerhardter and Gruber 2001). From this viewpoint, a regional supportive environment that appears between the "production environment « and the "market environment « plays an important role. It represents relationships that relative to production factors do not belong among normal market relationships but are of key importance in the work of companies (exchange of information, cooperation, strategic connections). A supportive environment is especially important for small and medium-sized companies that often do not have access to resources that would allow them to introduce innovations independently. The development of a supportive environment is not inevitable or certain since three important conditions are required: a special economic structure (size and branch), positive location factors (infrastructure, quality of life), and synergy effects (research institutions, risk capital, available labour force) (Maier and Obermaier 1999). 
According to data from the World Bank, human capital represents the largest share (64\%) in the structure of the entire capital defined as production capital, followed by natural resources $(20 \%)$ and financial capital (16\%) (Lorber 2002). It is imperative here to consider human capital more broadly, as social capital, because it influences numerous production processes. Bourdieu considers it the aggregate of actual or potential resources that derive from the permanent network of more or less institutionalized relationships, mutual acquaintances, or social respect. It is understood similarly by Putnam (1995; cited after Jarke et al. 2003), who defines it as the properties of a social organization such as networks, norms, and trust that make cooperation easier and thus contribute to the mutual benefit.

The common success of individual actors in a regional economy not only means the more permanent success of the region but also encourages new entrepreneurs to start their businesses in this cluster (Szyperski 2003). However, for the development of such areas, capital - above all, risk or venture capital - is very important, and this in fact develops in tandem with the technological and entrepreneurial base and is closely linked to innovative milieus.

Knowledge is becoming a major location factor and itself causes major changes in a region. Raw materials, labour force, and land are no longer decisive factors and the leading role has gone to the spatial concentration of related activities and the production of knowledge (social capital). This has definite consequences in an urban region: the division of labour is no longer clear cut, numerous new job descriptions appear, and new skills are needed because workers must perform increasingly diverse tasks. The occurrence of clusters is characteristic for practically all activities where knowledge has decisive significance: biotechnology, computer science and informatics, the media industry, the automobile industry, etc. Correspondingly, the linking of companies occurs with scientific institutions that are specializing and upgrading in a similar way (university centers, technological parks, fairs)

\section{Interaction of research, cooperation, and competition of cities/regions - the case of Ljubljana}

The cooperation and competition of cities/regions are two sides of the same coin. In the case of the small and medium-sized cities characteristic of Slovenia, this is particularly important from the developmental aspect. Along with attempts to cooperate, as a rule in conditions of globalization, competition is increasingly evident: »... The existence of competitiveness on all levels-even among partners within a leading and unified city region - is becoming a fact in the contemporary world ... (Sturm 2000). Under the pressure of balanced competitiveness cooperation is acquiring greater importance. The relationship between the cooperation and competition of cities is close, their common denominator being creativity. Competition is a decisive factor for cooperation within and between urban regions (Bergmann and Jakubowski 2001).

Competitiveness between cities is not a goal for its own sake, but where it functions it promotes mutual cooperation for the common benefit of two or more partner cities. It means the decentralized cooperation of individual activities and, furthermore, in the framework of cooperative »self-regulation « systematically promotes overall social development throughout the entire social community (region), particularly in cities.

As a principle of market regulation, competition is usually identifiable as the striving for the higher quality or lower price of goods and services among participants in the market. Modern market allocation mechanisms also support decentralization structures, and in addition, the business actions of the actors originate in maximization principles of profit and contradict the standardization characteristic of spatial planning. On the other hand, balanced competitiveness among urban regions increases efficiency and encourages optimal investments relative to available funds. Positive results can be expected for the following reasons: first, a positive message is given to all local and regional actors that they must improve their concrete activities and further develop their concepts, organizational forms, and measures, which in the final phase means a process of selection. The institutionalization of competitiveness is also a challenge for the promotion of efficiency among sociopolitical communities, for lowering costs while increasing the quality of the offer not only in the static sense but above all from the dynamic perspective. It reveals 
new possibilities for innovative processes. The expected success would be the better adaptability and mobility of location factors in a specific environment. »... In their final form, the positive consequences of competition among cities are: constant improvement of the economic actions and the reconciliation of expectations of the citizens and companies with the work of the administration. Thus, efficiency in the allocation of activities is increased, and economic effects are guaranteed ..." (Götz 1998). The skeleton conditions for mutual linkage and the effectiveness of balanced competitiveness are presented below.

The spatial effects of the activities shown above can also be explained using the direction, intensity, and the start and end points of flows (e.g., the migration of goods and population). From the economic viewpoint, competition leads to the formal and informal institutionalization of the more economizing and mobile factors, where the choice or selection of (modern) location factors plays an important role (among which, for example, the migration of companies and population to the suburbanized outskirts of cities has a visual impact).

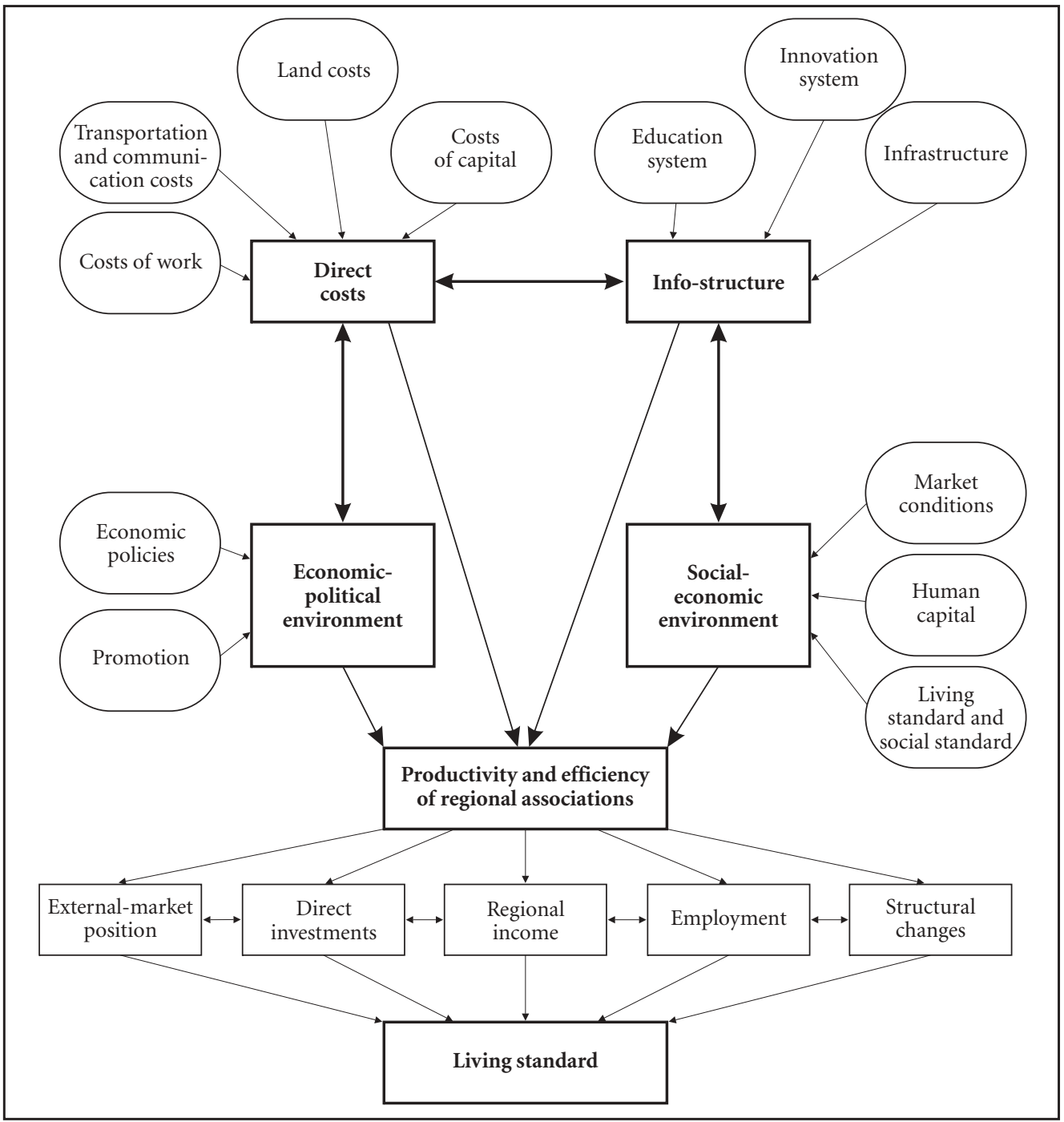

Figure 1: Determinants of Balanced Competitiveness of Cities/Regions (adapted from Mayerhofer 1998). 


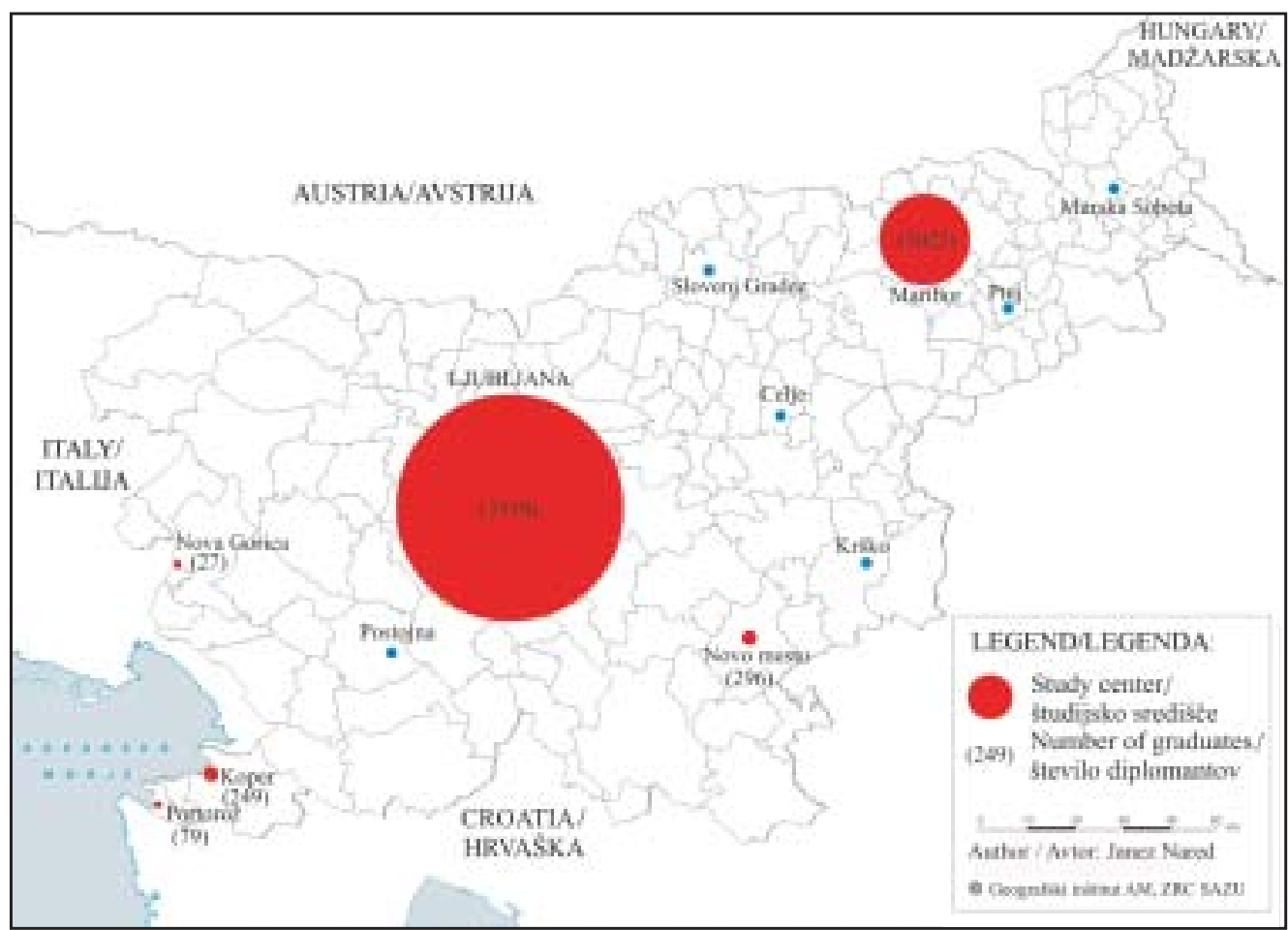

Figure 2: Graduates from university and independent higher education institutions in 2003.

Slovenia's urban system is barely identifiable by European standards since only the Ljubljana urban region has more than half a million inhabitants. In addition to cities with populations over one million (Vienna, Munich, Budapest, Prague, Milan, Zagreb), the immediate vicinity of central Europe also has a number of cities with populations between 100,000 and 400,000 inhabitants that have a university and research tradition, are relatively close to each other, and are located - with the exception of Italian cities - in medium-size countries. In spite of this, radical changes in spatial relationships can be anticipated in the networking of cities in the coming decades as medium-sized as well as large cities search for cooperation partners. Cross-border cooperation is certainly one of the unique opportunities for overcoming the weak development and research capacities of some cities. Thus on the basis of its geopolitical situation (also stimulated by the proximity of the outer European Union border), the Ljubljana (and Slovenia's) urban network is increasingly becoming a part of globalization streams and acquiring an increasingly supranational character through its production and service activities. Here, the network of three university centers along the fifth European development corridor plays a special role.

Ljubljana is the seat of all government ministries and the majority of governmental services. The city therefore attracts numerous complementary activities closely connected with the public administration; furthermore, it is also the most suitable center for company headquarters since the proximity of administrative organs facilitates the flow of information between companies and government institutions. As the capital city with a central position, Ljubljana enjoys numerous advantages that further raise its location attractiveness and its location rent. Public administration and companies with high added value largely employ a more educated labour force, which is also better paid, and this is reflected by the average incomes in the city. In 2003, the average gross income in Ljubljana exceeded the average gross income in Slovenia by $23.5 \%$. Because of this, Ljubljana is also highly above average in gross base for income tax per capita, which exceeds the national average by $38.9 \%$. A benefit of the latter is the relatively high inflow into the city coffers, since income tax is one of the principal sources of financing for Slovenia's municipalities. A further advantage of jobs in public administration is their relative stability and security. As a strong employment 


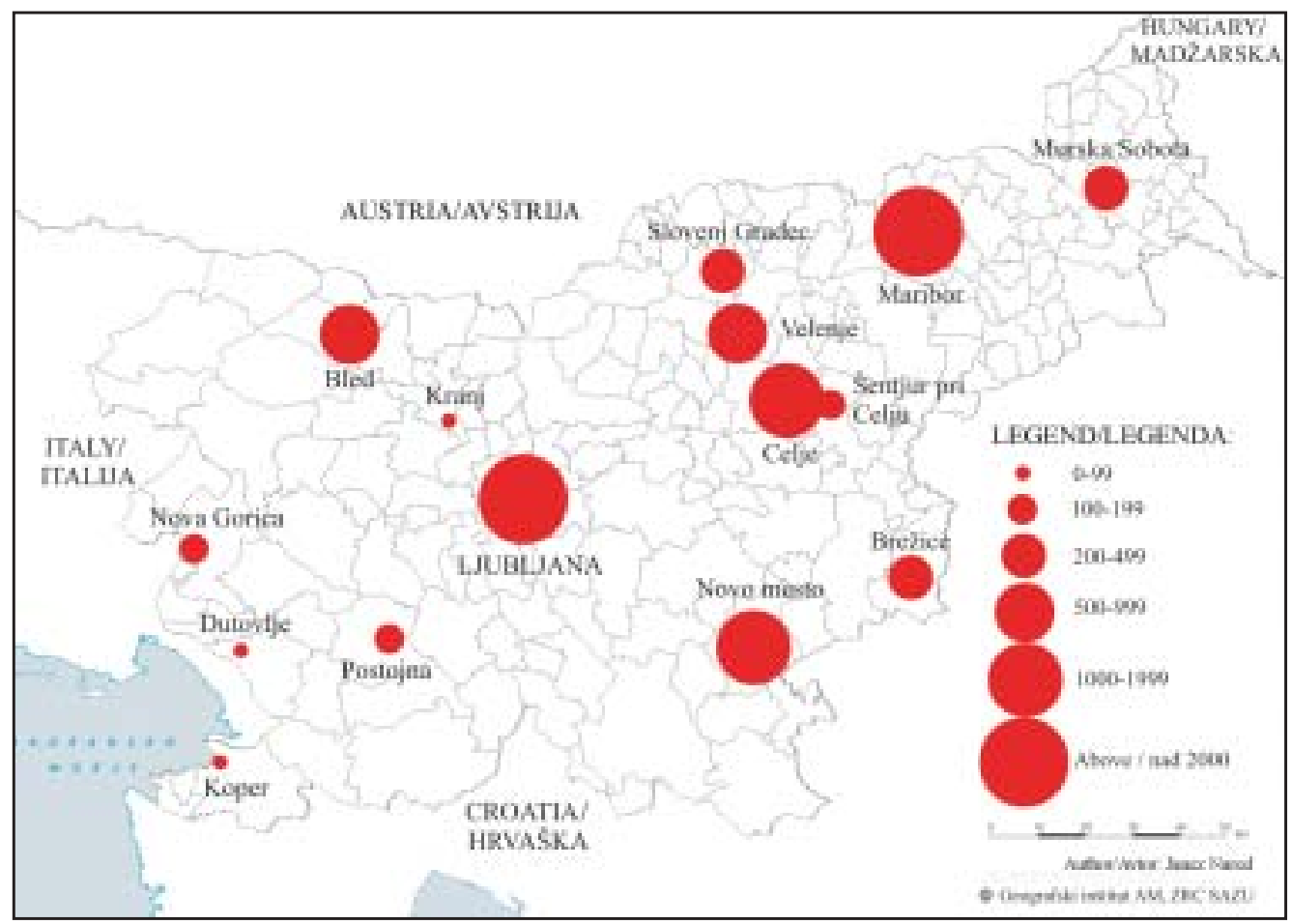

Figure 3: Number of students registered in higher education institutions in the 2003/04 study year.

center, Ljubljana has attracted workers from the entire country for a long time - including from the marginal areas of Slovenia - and generally employs the better-educated population. However, while the concentration of population reduces the per capita cost of public services, it also increases the pressure on the environment, which can lead to the occurrence of diseconomies or other negative effects resulting from such concentration.

In view of its central position, Ljubljana receives ample national financing, among which funds for health care, culture, education, and other services stand out. For cultural activities, for example, the Central Slovenia region receives almost $45 \%$ of all direct regional grants, the major proportion of which go to the city itself. Similarly, it stands out relative to funds received for education (33\%), information services (28\%), and health care (50\%). Relative to development, these spheres are important since in the majority of cases they raise the standard of living of the population - from the viewpoint of endogenous regional development, one of the key factors in the attractiveness of a city or region - and thus raise the quality of the so-called "soft « location factors such as social capital, the attractiveness of an area from the viewpoint of the cultural offer, and the overall offer of services.

Ljubljana is the largest university center in Slovenia according to both the number of researchers and professors and the number of students. It hosts two hundred research organizations, some $42 \%$ of all research organizations in the country, that employ 6566 researchers or almost two thirds of all Slovene research personnel. With its diverse education and research offer, the University of Ljubljana attracts a large proportion of Slovenia's undergraduate students. In the 2004/05 school year, the University of Ljubljana had 57064 registered undergraduates, some $64 \%$ of all undergraduates in Slovenia. Its proportion of postgraduate students is even higher, reaching almost 70\% (2003/04).

Ljubljana's proportion of students enrolled in the alternative higher education institutions scattered throughout the city is also high since the entrance requirements for such schools are less demanding than for 


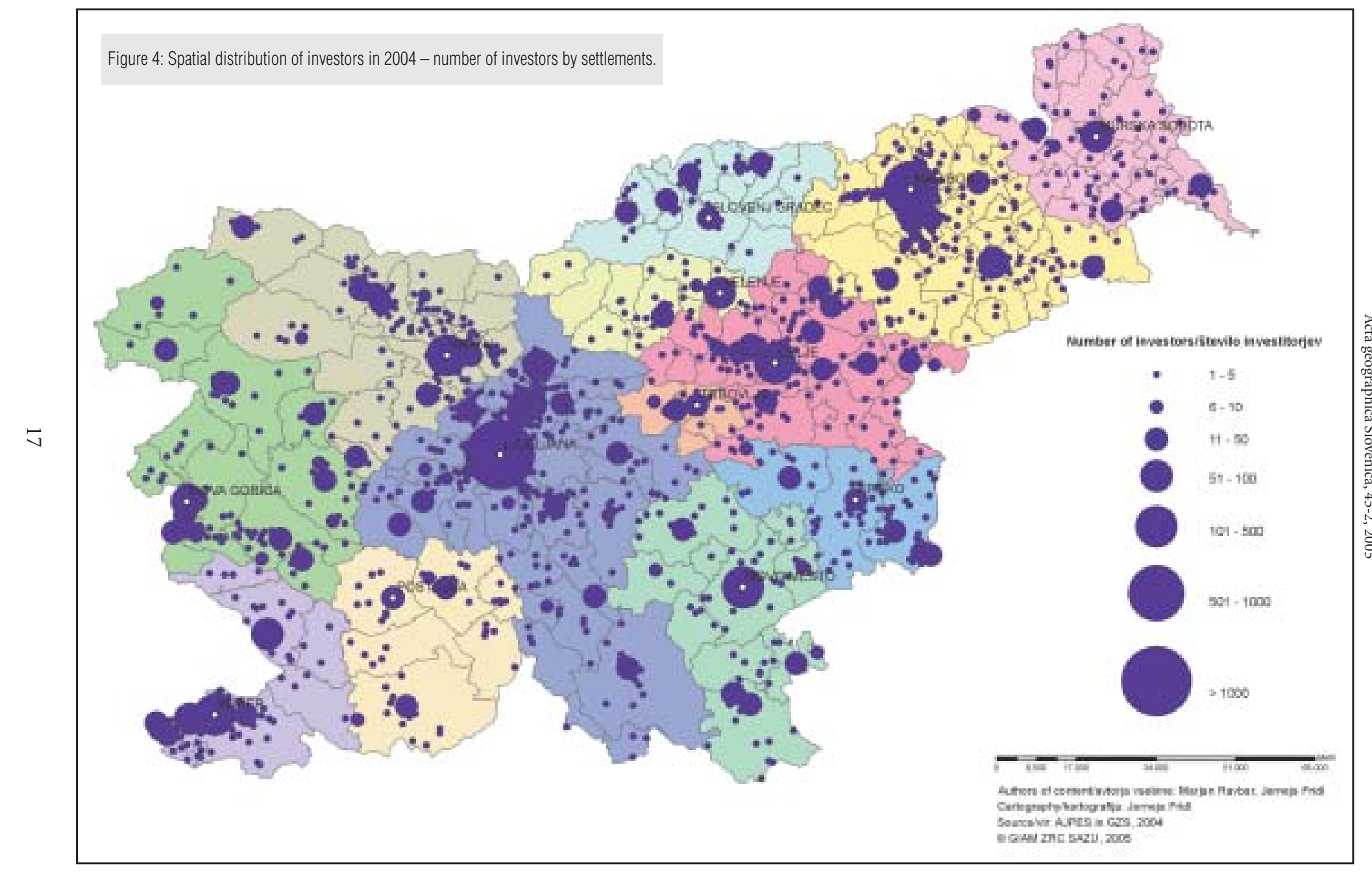




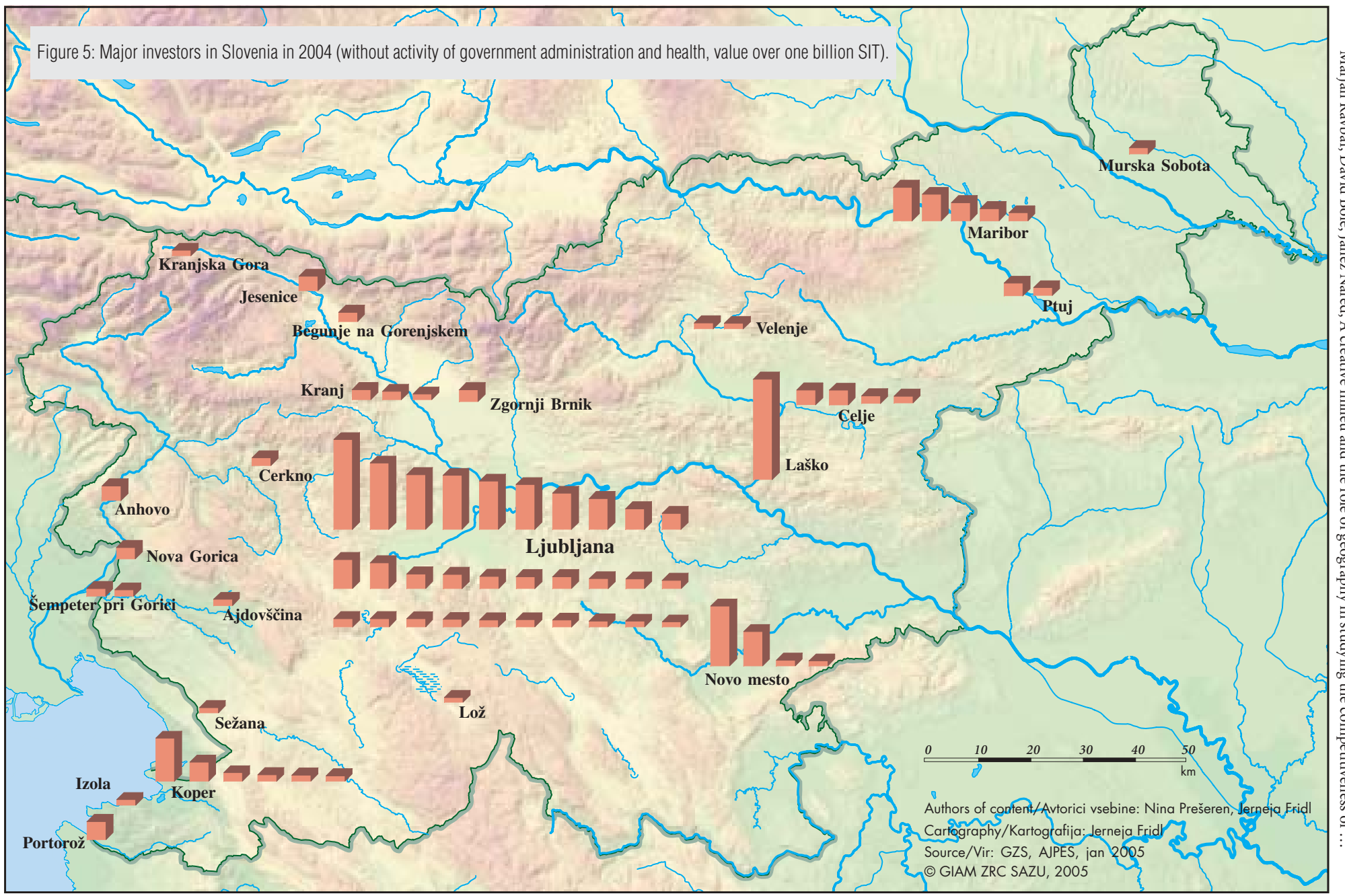


university faculties; nevertheless, they are of exceptional importance because their primary goal is close attachment to business. These schools are intended to ensure a flow of professional personnel with more practical experience who will be able to tackle demanding problems occurring in the companies where they are employed immediately after finishing their studies.

Students studying in Ljubljana are an important source of income for the city economy since they pay for numerous services such as housing, public transport, dining, and cultural and sport events. Many of these activities are also subsidized by the state. Thus students, who comprise about one sixth of the city population, represent an important segment of consumption. The importance of students to the city economy is additionally increased by the multiplication effect, which produces an increase in employment in the sphere of education itself as well as in other branches.

The city must provide for the opening of new, attractive, and high-quality jobs that will raise the purchasing power of the population and simultaneously allow the city to become and remain a magnet for the better educated population, as much on the supranational level as on the national level. In this context, new investments that create new jobs are exceptionally important. In 2004, 7850 investors were active in Slovenia, investing a sum total of 760 billion SIT. Also illustrative is the amount of investment per capita, which totaled 387,000 SIT. This was by far the highest in the Central Slovenia region where it exceeded the Slovene average by 1.82 . The spatial distribution of investments at first sight indicates a relatively high level of distribution throughout the country, with at least one investment per 1276 settlements or on average in every fifth settlement $(21 \%)$. A more detailed analysis, however, shows that in the majority of settlements, the investments were of smaller amounts. All the major investments (above ten million SIT) with a total value of almost 470 billion SIT or $87 \%$ of all investment in Slovenia - were focused on forty-four settlements. Among them, Ljubljana stands out with a total of 1904 investments with a total value of 227 billion SIT or $42 \%$. The ratio between investments in Ljubljana and Maribor, which takes second place, is $1: 6$, meaning that the total value of investments was six times higher in Ljubljana than in Maribor. The activity structure is also equally representative with positive deviations from the average primarily in public investments and the economic infrastructure. The details are illustrated in figures 4 and 5.

\section{Conclusion}

High-quality investment and the jobs linked to it are of key importance for the development of a city because as a result of competition on the international market and increasing globalization they lead to key innovations that either reduce production costs or offer new products, meaning an offer equal to that of others. In numerous cases, the innovative areas that geographers label »industrial districts « have proven to be the driving force behind a development breakthrough. These areas rely on the close proximity of companies with similar production orientations, allowing companies to specialize narrowly and draw upon the wealth of knowledge the environment offers. This leads to close cooperation between companies that is enriched by an exchange of goods and cooperation that benefits all partners. The strong specialization in one branch also quickly attracts other supporting organizations that are essential for the operation of production companies due as much to the narrow specialization of these supportive organizations as to their proximity. Of key importance here is the rapid flow of information, which in a creative milieu is essential for the development of products and the search for markets and market niches. In developing this type of environment, city authorities play an important role since they must ensure that administrative procedures run as quickly as possible and are uncomplicated and of high quality. In the case of Ljubljana, it is inappropriate to expect production activity to focus on just one branch, but the relatively small territory enables the existence of many entrepreneurial networks of this type that can be closely intertwined. The cooperation of research institutions and their close involvement in these networks is also very desirable. If this is ensured, we can talk about creative milieus that along with the production organization itself also incorporate strong support for the social environment and administration and research organizations.

Attachment to an area, which can only be achieved by insuring a high standard of living, a diverse cultural offer, and numerous activities that raise the attractiveness of an area, is of exceptional importance. 
Here, we encounter the key problem that Ljubljana faces. Because of strong suburbanization trends, many of »its « workers settled in the wider surroundings. In order for Ljubljana to ensure an attractive environment and on this basis the greater interest of the area's population in development and progress, the coordination of development activities on the regional level is essential since this will ensure the inclusion of all the population and similarly will increase the possibility of synergistic development effects. The continuing development of Ljubljana will only be possible if the purchasing power of the population gravitating to Ljubljana is high enough.

If we wish to increase the importance of Ljubljana relative to the metropolitan agglomerations in the wider neighbourhood, it is necessary to stimulate its internal innovation dynamics, particularly because it has sufficient and large enough development research potential as well as economic and population capacities at its disposal. In spite of this, it must develop its independence and thus in the long term ensure itself innovation possibilities. Shortcomings can turn into advantages if Ljubljana is aware of its special relationships on the national level and exploits its comparative advantages for future development. This means it is necessary to establish cooperation and responsible relations with places in its gravitation area. Those relations should also allow »rural « municipalities to participate in the innovative potential and economic success of their center.

The formation of a successful network of cities is the most important element in successfully satisfying economic interests and for undertaking joint tasks on supralocal levels. Here, a polycentric urban system is the necessary foundation for consolidating the network of linked cities and derives from the principle of ensuring equal living and working conditions for all of the population in the entire territory of a country, and, for example, means organizing the network of higher-level public institutions to provide access within about half an hour, given the present level of motorization. Thus, the polycentric urban system is a counterweight to existing trends and fosters a dual strategy of »equalized « urban life. The first goal is the preservation and promotion of highly specialized jobs in centers of national importance and means interweaving the spectrum of economic activities with centers of lower regional importance and partner cities around the world. In this case, formation of an intercity network between neighbouring (and more distant) cities of similar size is essential. The second goal is to establish and deepen economic cooperation between cities and their hinterland areas, which is mutually beneficial due to the complementing of functions. This is achieved by establishing a competitive balance within a network of cities such as the neighbouring central European cities. Originating in the goals and ideas of continuing sustainable development and a successful foundation for a network of settlements that ensures a fair distribution of human resources, the efficient use of social resources, and limits the consumption of natural resources, the economic and public (social) infrastructure and supply services will create a settlement structure along with

Figure 6: Instrumental importance of individual aspects in the orientation of balanced competitiveness - the case of Ljubljana.

\begin{tabular}{llc}
\hline Degree of centrality & $\begin{array}{l}\text { Degree of influence of individual aspects in the orientation of fundamental spheres of competitiveness } \\
\text { relative to their position and function in the network of settlements }\end{array}$ \\
\cline { 2 - 3 } & $\begin{array}{c}\text { Settlement structure } \\
\text { infrastructure }\end{array}$ & $\begin{array}{c}\text { Supply services } \\
\text { Production and } \\
\text { creative milieu }\end{array}$ \\
\hline $\begin{array}{l}\text { National center } \\
\text { (Ljubljana) }\end{array}$ & & \\
\hline Centers of national \\
importance (Kranj, \\
Novo mesto) \\
\hline Centers of regional \\
importance (Kamnik, \\
Domžale, Škofja Loka, \\
Vrhnika, Grosuplje) \\
\hline Centers of local \\
importance (about thirty) \\
\hline
\end{tabular}


the production and creative milieu. The degree of influence of individual aspects in orienting fundamental spheres of balanced competitiveness varies relative to their position and function in the network of settlements. Their significance on the model level is represented by the relative size of the squares shown in the table below.

It is indisputable that in addition to its economic role and regardless of its relatively small size, important research, cultural, and social impulses originate in Ljubljana. Two contradictory processes are characteristic of its further spatial development: demographic and settlement growth »outwards « with the transformation of predominantly agricultural land use to mixed (farming-urban) land use and growth »inwards « with the transformation of income-extensive land use to income-intensive land use. In a market economy, activities that do not create enough income per unit of surface to cover all expenses, including urban rent, cannot survive in urban centers. Thus, new commercial and business centers appear on abandoned (predominantly) industrial surfaces close to urban centers that can cover the rise in urban costs through the more intensive use of land. Non-profit public (including administrative) activities that contrary to market laws remain in central locations must be subsidized by the state if retaining them in the more accessible locations is desired.

\section{References}

Audretsch, D., B. 2003: Globalization, Innovation and the Strategic Management of Places. In: Bröcker, J.; Dohse, D., Soltwedel, R. (eds.) 2003: Innovation Clusters and Interregional Competition. Springer. Berlin.

Bergmann, E., Jakubowski, P. 2001: Strategien der Raumordnung zwischen Kooperation und Wettbewerb. Informationen zur Raumentwicklung 8. Berlin.

Bergmann, S. 2003: Industridistrikte in der Provinz Pordenone - Netzwerkbildung von KMUs im peripheren Grenzraum. Arbeitsmaterialien zur Raumordnung und Raumplanung 222. Universitaet Bayreuth, Lehrstuhl Wirtschaftsgeographie und Regionalplanung. Bayreuth.

Bröcker, J., Dohse, D., Soltwedel, R. 2003: Clusters and Competition as Engines of Innovation - An introduction. In: (uredniki: Bröcker, J., Dohse, D., Soltwedel, R. (eds.) 2003: Innovation Clusters and Interregional Competition. Springer. Berlin.

Burkhardt, T., Lohman, K., Marowsky, G., Thome, C. 2003: Beteiligungskapital bei Aus- und Neugründungen von High-Tech-Unternehmen aus Forschungsinstituten: Erfahrungen im Bereich Lasertechnik im Raum Göttingen. V: Nathusius, K. (ed.) 2003: Wirkungen des regionalen Kontexts auf Unternehmensgründungen. Josef Eul Verlag. Lohmar - Köln.

Chancen und Moeglichkeiten eines kreativen Milieus fuer die Stadt- und Regionalentwicklung. 1996. Bayreuth. Diez, M., A. 2001: New Approaches to Evaluating Regional Policy The Potential of a Theory-Based Approach. Internet: http://www.greenleaf-publishing.com/gmi/gmi36.htm (19.2.2005).

Diez, M., A., Esteban, M., S. 2000: The Evaluation of Regional Innovation and Cluster Policies: Looking for New Approaches. Internet: http://www.europeanevaluation.org/docs/22_diez.pdf (19.2.2005).

Gerhardter, G., Gruber, M. 2001: Regionalförderung als Lernprozess: Evaluierung der Förderungen des Bundeskanzleramtes für eigenständige Regionalentwicklung. Schriften zur Regionalpolitik und Raumordnung 32. Republik Österreich, Bundeskanzleramt. Wien.

Goederitz, J., Roland, R. 1957: Die gegliederte und aufgelokerte Stadt. Archiv fuer Staedtebau und Landesplanung 4. Tuebingen.

Götz, C. 1998: Kommunale Wirtschaftsförderung zwischen Konkurrenz und Kooperation. Regensburg.

Heeb, S. 2003: Hochschulen - Wissensinkubatoren der Region. In: Nathusius, K. (ed.) 2003: Wirkungen des regionalen Kontexts auf Unternehmensgründungen. Josef Eul Verlag. Lohmar - Köln.

Internet 1: http://www.corecities.com (1.4.2005).

Isbary, D., von der Heide, H.-J., Mueller, G. 1969: Gebiete mit gesunden Struktur und Lebenbedingungen. Merkmale und Abgrenzung 57. Hannover.

Jarke, M., Klamma, R., Marock, J. 2003: Gründerausbildung und Gründernetze in Umfeld technicher Hochschulen: ein wirtschaftsinformatischer Versuch. In: Nathusius, K. (ed.) 2003: Wirkungen des regionalen Kontexts auf Unternehmensgründungen. Josef Eul Verlag Lohmar - Köln. 
Konstadakopulus D., Christopoulus D., 2004: Innovative milieux and networks, and technological change and learning in European regions: technology policy and innovation strategies. Internet: http://www.intech.unu.edu/publications/conference-workshop-reports/seville/konstant.pdf (May 2004)

Krätke, S., Scheuplein, C. 2001: Produktionscluster in Ostdeutschland. Methoden der Identifizierung und Analyse. VSA. Hamburg.

Kürki S. 2003: Creating regional knowledge networks - the case of Epanet in the south Ostrobotnia, Finland. Reinventing Regions in the Global Economy Academic Conference, 12.-15. April 2003. Pisa.

Lorber, L. 2002: Vloga geografije pri interdisciplinarnem načrtovanju regionalnega razvoja. Dela 18. Ljubljana.

Maier, J.; Obermaier, F., 1999. Kreative Milieus und Netzwerke. Neue Erklärungs und Strategieansätze in Bayern. Arbeitsmaterialien zur Raumordnung und Raumplanung Heft 186. Bayreuth.

Morgan, K. 1997: The Learning Region - Institution, Innovation and Regional Renewal. Regional Studies 31, 5. Cambridge.

Nathusius, K. 2003: Zum zeitlichen Zusammenhang zwischen regionaler Clusterbildung von Hoch Technologie Unternehmen und Venture Capital Gesellschaften: Die US Regionen Route 128 / Boston und silicon Valley im Vergleich. In: Nathusius, K. (ed.) 2003: Wirkungen des regionalen Kontexts auf Unternehmensgründungen. Josef Eul Verlag. Lohmar - Köln.

Niessler, R. 2000: Das Europäische Raumentwicklungskonzept: Ein Instrument zur Förderung einer ausgewogenen und nachhaltigen Entwicklung der Europäischen Union. In: Hovorka, G. 2000: Zukunft mit Aussicht. Beiträge zur Agrar-, Regional-, Umwelt- und Sozialforschung im ländlichen Raum. Forschungsbericht 45 . Wien.

Sassen S. 2002: Cities, foreign policy and the global economy. European cities in a global era. Internet: http://www.mcrit.com/espon_scenarios/files/DOCUMENTS/european_cities.pdf (1.4.2005).

Sturm, P. 2000: Region Frankfurt/RheinMain. In: Informationen zur Raumentwicklung 11-12.

Suchanek, A. 1998: Nachhaltigkeit und Wettbewerb. In: Renner, A., Hinterberger, F. (ed.). Zukunftsfähigkeit und Neoliberalismus. Baden-Baden.

Szyperski, N. 2003: Regional Clustering - zwischen Bremse und Motor? In: Nathusius, K. (ed.) 2003: Wirkungen des regionalen Kontexts auf Unternehmensgründungen. Josef Eul Verlag. Lohmar. Köln. 


\title{
Ustvarjalno okolje in vloga geografije pri proučevanju konkurenčnosti mest: primer Ljubljane
}

\author{
UDK: 911.375(497.4 Ljubljana) \\ COBISS: 1.01
}

IZVLEČEK: Prispevek sestavljata dva dela. Prvi temelji na teoretskih geografsko-razvojnih dejavnikih uravnotežene konkurenčnosti mest (regij) v pogojih globalizacije in poudarjene vloge ustvarjalnega okolja kot temeljnih razvojnih gibal. Znanje postaja poglavitni lokacijski dejavnik in povzroča spremembe v pokrajini. Surovine, delovna sila, tržišče in zemljišče niso več odločujoči, odločilna postaja prostorska koncentracija sorodnih dejavnosti in ustvarjanje novih znanj. V drugem delu pa z empiričnimi izsledki podajamo pomen Ljubljane in njeno vlogo $\mathrm{v}$ sistemu inovativnih urbanih središč nasproti velemestnim aglomeracijam $\mathrm{v}$ širši soseščini. Njen položaj utemeljujemo z geografskimi razsežnostmi inovacijske dinamike kot temeljnega razvojnega generatorja za celoten državni urbani sistem ter vrednotimo njen razvojno raziskovalni potencial in investicijske, gospodarske ter populacijske zmogljivosti z vidika priložnosti, ki jih ponuja osrednja lega in funkcija glavnega mesta.

KLJUČNE BESEDE: ekonomska geografija, ustvarjalno okolje, učeče se regije, uravnotežena konkurenčnost, omrežje mest, grozdenje, Ljubljana, ljubljanska mestna regija.

Uredništvo je prejelo prispevek 17. oktobra 2005.

\section{NASLOVI}

\section{Marjan Ravbar, dr.}

Geografski inštitut Antona Melika

Znanstvenoraziskovalni center Slovenske akademije znanosti in umetnosti

Gosposka ulica 13, SI - 1000 Ljubljana, Slovenija

E-pošta: marjan.ravbar@zrc-sazu.si

David Bole, univ. dipl. geog.

Geografski inštitut Antona Melika

Znanstvenoraziskovalni center Slovenske akademije znanosti in umetnosti

Gosposka ulica 13, SI - 1000 Ljubljana, Slovenija

E-pošta: david.bole@zrc-sazu.si

Janez Nared, univ. dipl. geog. in prof. soc.

Geografski inštitut Antona Melika

Znanstvenoraziskovalni center Slovenske akademije znanosti in umetnosti

Gosposka ulica 13, SI - 1000 Ljubljana, Slovenija

E-pošta: janez.nared@zrc-sazu.si

\section{Vsebina}

1 Uvod

2 Učeče se regije/mesta - vloga grozdenja

(mreženja) na geografsko

preobrazbo družbe

Značilnosti učečih se regij

4 Součinkovanje raziskovanja, sodelovanja

in konkurenčnosti mest/regij -

primer Ljubljane 


\title{
1 Uvod
}

Prispevek je zasnovan iz dveh medsebojno povezanih delov. Prvi je poskus utemeljitve nekaterih geografsko-razvojnih dejavnikov konkurenčnosti mest (regij) v pogojih globalizacije in poudarjene vloge ustvarjalnega okolja kot temeljnih sodobnih razvojnih gibal. V njem namenjamo poudarek prostorskim vplivom in posledicam uravnotežene konkurenčnosti, zlasti »novi terciarizaciji mest«, globalnemu delovanju, geografskim razsežnostim tehnološkega razvoja, razporeditvi sodobnih investicijskih aktivnosti, kot razvojnim pospeševalcem konkurenčnosti, lokacijskim dejavnikom, deregulaciji, preobrazbi infrastrukturnih sistemov, prepletanju in povezovanju med omrežji mest, grozdenju. Zaradi spremenjenih razmer se preobražajo funkcionalne delitve opremljenosti mest $\mathrm{z}$ družbeno infrastrukturo, ki je neobhodnega pomena za obstoj ustvarjalnega okolja, zlasti pri gospodarskih povezavah, pospeševanju raziskovanja in komplementarnih dejavnostih. Prispevek je povezan s preučevanjem vplivov ustvarjalnega okolja na spremembe v prostorsko-razvojnih strukturah mest in njihovih vplivnih območij.

V drugem delu z empiričnimi izsledki podajamo pomen Ljubljane in njeno vlogo v sistemu inovativnih urbanih središč v primerjavi z velemestnimi aglomeracijami v soseščini. Njen položaj utemeljujemo z geografskimi razsežnostmi inovacijske dinamike kot temeljnega razvojnega generatorja za celoten državni urbani sistem ter vrednotimo njen razvojno raziskovalni potencial in investicijske, gospodarske ter populacijske zmogljivosti z vidika priložnosti, ki jih ponujata osrednja lega in funkcija glavnega mesta.

Preobrazbi mest zaradi vplivov ustvarjalnega okolja, kot eni izmed pomembnih sestavin strukturnih sprememb v pokrajini, se v slovenski geografski literaturi posveča premalo pozornosti. Na nekatera odprta vprašanja bomo skozi kritični raziskovalni pogled poskusili odgovoriti, hkrati pa tudi odstreti nove razsežnosti v ekonomski geografiji, kot izziv za nadaljevanje poglobljenih razprav.

\section{Učeče se regije/mesta - vloga grozdenja (mreženja) na geografsko preobrazbo družbe}

\begin{abstract}
Z iskanjem zapletenih vsebin in dejavnikov inovativno naravnanega razvoja se že dalj časa ukvarjajo ekonomisti, gospodarstveniki, sociologi in regionalni planerji. Manj (slovenski) geografi, čeprav gre za hvaležno področje, povezano s sodobnimi strukturnimi spremembami v pokrajini. Klasične raziskave, ki so doslej opozarjale na pomen regionalne opremljenosti in prikazovale spremembe v prostorskih in gospodarskih strukturah, ponudbi storitvenih dejavnosti, prisotnosti visoko produktivnih raziskovalnih dejavnosti, prometni povezanosti in kakovosti življenjskega okolja, nadomeščajo novi vidiki vrednotenja odnosov znotraj geografsko zaokroženih regionalnih skupnosti. Za to se ob številnih diskusijah najpogosteje uporablja pojem kreativni milje ali ustvarjalno okolje, pa tudi drugi komplementarni pojmi (učeče se regije, industrijski distrikti, inovativni grozdi), ki opozarjajo na geografske razsežnosti povezovanja znanstveno-tehnoloških centrov z ostalimi gospodarskimi omrežji ter na tesno institucionalno in neformalno vpetost v družbeno okolje, kar ima pomembne prostorske implikacije na regionalni ravni. Po svoje je to nov pogled in temu je prilagojena svojstvena, vendar sodobna interpretacija vsebin v regionalni geografiji.
\end{abstract}

Sodobne razvojne politike od geografskih raziskav zahtevajo celovito presojo homogenih pokrajinskih območij in oceno posledic osrednjih (ključnih) problemov regije na podlagi naravnih razmer ter upoštevanja interesov avtohtonega prebivalstva. Na socialno-ekonomskem področju igrata odločujočo vlogo kvalifikacijska in izobrazbena struktura, s katerima se povečujejo možnosti vključevanja v inovacijske gospodarske tokove, kajti »od znotraj « določena razvojna identiteta in sociokulturna ustvarjalnost sta brez dvoma najmočnejša argumenta za vsebinsko (pre)oblikovanje obstoječih razvojnih nesorazmerij. Z ustrezno izobrazbeno strukturo prebivalstva se oblikuje ustvarjalno okolje, ki praviloma tvori prostorsko zaključeno skupnost, pri čemer so administrativne meje manj pomembne oziroma ne predstavljajo razpoznavnega merila, temveč je merilo homogenost $\mathrm{v}$ načinu ravnanja in zmožnost prilagajanja. Na podlagi tovrstnih preučitev pa je možno razvijati primerno razvojno politiko s pomočjo avtonomije finančnih odločitev na regionalni ravni. 
Učeča se mesta/regije najlažje opišemo s specifičnimi procesi, ki se odvijajo znotraj njihove ekonomije, trga delovne sile in tehnološkega napredka. Vsi ti dejavniki odpirajo možnosti boljšega političnega, kulturnega, družbenega in organizacijskega napredka v mestu/regiji (Konstadakopulus in Christopoulus 2004). Mnogi povezujejo učeča se mesta in ustvarjalno okolje z globalno konkurenčnostjo. Mesta nikakor niso več samozadostna, marveč so vpeta v globalno ekonomijo. Prav tako niso imuna na širše družbene in politične spremembe v svetu. Strateška povezava med državo in globalno ekonomijo ne zdrži več, kajti vse bolj jasno postaja, da regionalna raven, povezana $\mathrm{z}$ decentralizacijo funkcij pridobiva pomen. To pomeni, da so mesta in mestne regije kot razvojni generatorji poglavitni akter $v$ globalni ekonomiji. Vprašanje mestnih oblasti je, ali bodo te razmere izkoristile sebi v prid, kajti globalizacija prinaša pozitivne in negativne spremembe (Sassen 2002).

Ob tem se zastavlja vprašanje ali obstaja obči model usmerjenega razvoja, ki bo ustvaril razmere za nastanek ustvarjalnega okolja. Odgovor je večplasten: inovativnost je lahko posledica načrtnega razvijanja znanja in kopičenja ostalih sredstev, vendar je hkrati odvisna tudi od dejavnikov na katere težko vplivamo in so specifični za vsako geografsko okolje. Predpogoj za oblikovanje inovativnosti je tekmovalnost med gospodarskimi panogami, ki spodbujajo tehnološki razvoj in učenje ter povezovanje (sinergija) med podjetji. Učeča se regija nastane takrat, ko so ekonomski, geografski in družbeno-kulturni dejavniki v določeni regiji takšni, da spodbujajo tehnološki napredek, ustvarjajo znanje in tako skušajo ustvariti primerne razmere za gospodarski napredek.

Tehnološko in institucionalno učenje sta $\mathrm{v}$ sodobni ekonomiji priznana kot najbolj pomembna vira in sta razumljena kot proces, kjer posamezniki, organizacije in družba kot celota vlagajo v znanje in inovativnost. Slednja se oblikuje na podlagi številnih institucionalnih rutin in je povsem družbeno pogojena. Inovativnost $\mathrm{v}$ gospodarskih institucijah pomeni ponavljanje rutin, navad, oziroma vedenjskih vzorcev, ki vsebujejo prikrito znanje, ponavadi v obliki različnih spretnosti ali t.i. know how. Regije, ki povezujejo družbeno kohezivnost s principi inovativnosti in so hkrati odprte preostalemu svetu, imajo boljše razmere za učenje, saj pobirajo in identificirajo nove trende, nov razvoj tudi na globalni ravni.

Sposobnost učenja in inovativnosti lahko po analogiji fizičnega in človeškega kapitala imenujemo družbeni kapital (Morgan 1997). Družbeni kapital se nanaša na dejavnike družbene organiziranosti in norm, ki investicije pretvarjajo v fizični in človeški kapital, oziroma ju nadgrajujejo. Vse bolj ga razumemo kot bistveno sestavino uspešnega gospodarskega razvoja. Uspešnost mest/regij se skuša identificirati z različnimi značilnostmi, ki naj bi bile značilne za učeče se regije. Med njimi prevladujejo zlasti:

- stopnja izkoriščenja lokalnih človeških virov in visoka mobilnost delovne sile;

- gospodarska specializacija regije;

- močni inovativni stiki znotraj regije;

- visoka stopnja sinergije med lokalnimi podjetji;

- kolektivni proces učenja;

- ponavljajoči se procesi inovaciji in patentiranja novih spoznanj;

- močan kolektivni duh in poudarjena koordinacija razvojnih aktivnosti;

- močna lokalna in regionalna identiteta;

- močne povezave $\mathrm{z}$ »zunanjim« svetom.

Naslednja pomembna značilnost učečih se regij je njihovo povezovanje na podjetniški (podjetje s podjetjem) in tudi na regionalni ravni (mesto z mestom). Za ta proces, ki prinaša korist vsem v njem udeleženim akterjem, se je uveljavil pojem: mreženje (angl.: networking). Poznana tovrstna pobuda obstaja med angleškimi mesti in se imenuje središčna mesta (angl.: The core cities), ki obsegajo Birmingham, Bristol, Leeds, Liverpool, Manchester, Newcastle, Nottingham in Sheffield (Internet 1). Ta pobuda ima tudi institucionalizirano obliko z udeležbo mestnih oblasti, razvojnih agencij in ministrstev. V njej sprejemajo konkretne akcijske načrte, ki so usmerjeni k ustvarjanju konkurenčne regije v svetovnem merilu, t.i. ideopolisa. To je ideja organizacije The core cities, s katero označujejo regijo katere ključni elementi so univerza, letališče, ustvarjanje novih idej, intelektualni kapital in podjetniška samozavest. Z izobraženo delovno silo, tehnološkim razvojem in poslovno konkurenčnostjo se oblikuje regija, ki privlači strateške vlagatelje in ustvarja samoohranjajoč se sistem gospodarske rasti ter investicij v znanost in izobraževanje. 
Prostorska koncentracija podjetij s sorodno branžno strukturo je splošno obeležje za uspešen gospodarski razvoj. Grozdenje ima svoje korenine že v obdobju zrele faze industrijske revolucije, ko so za tedanje razmere visoko integrirana fordistična združenja povezovalne procese razvila do optimalnih razsežnosti. Povezovalnim procesom grozdenja v industriji so pozneje sledile še dejavnosti finančnega sektorja, podjetniško naravnane služnostne dejavnosti in tudi »kulturna« proizvodnja. V 1980. letih so gospodarske povezovalne procese intenzivno preučevali raziskovalci z različnih med seboj nepovezanih področij, med njimi tudi ekonomski geografi in regionalni ekonomisti (Scott 2000). V zadnjih letih se spoznanja različnih strok ter njihovih teoretskih in empiričnih izsledkov medsebojno oplajajo in preučevanje grozdenj se je uveljavilo tudi v sodobni ekonomski geografiji. Skupni imenovalec je preučevanje sistemizacije značaja grozdenja kot specifičnega spleta povezav proizvodnih in institucionalnih odnosov, kot instrumenta v verigi ustvarjanja dodane vrednosti. Pojem grozdenje pomeni povezanost proizvodnih, služnostnih in distribucijskih gospodarskih združenj, ki so (so)udeleženi pri izdelavi in prodaji določenega proizvoda oz. proizvodne družine ali storitvenih dejavnosti (Krätke in Scheuplein 2001). Verigo ustvarjanja dodane vrednosti poznamo v različnih pojavnih elementih/funkcijah med množico podjetij, ki jo sestavljajo bolj ali manj kompleksni vzorci delitve dela.

Ideja o grozdih vse od Marshallovega dela o lokacijski izbiri in industrijskih distriktih ni imela nikoli tako velikega pomena kot $\mathrm{v}$ preteklem desetletju, kar je posledica želje podjetij po zvišanju njihove konkurenčnosti in vlad po izkoriščanju novih virov gospodarske rasti. Prav v geografsko koncentriranih mrežah oziroma grozdih se namreč realizira največ regionalne dodane vrednosti in rasti zaposlenosti, zato so članstvo v grozdih in mreže med podjetji po prepričanju mnogih temeljno sredstvo za spodbujanje produktivnosti in konkurenčnosti podjetij (Bröcker in sodelavci 2003).

\section{Značilnosti učečih se regij}

Prostorska koncentracija podjetij in medsebojna povezanost povečujeta inovacijsko sposobnost okolja, $\mathrm{s}$ čemer so medpodjetniške mreže $\mathrm{v}$ konkurenčnih razmerah in globaliziranem gospodarstvu pridobile pomen. Mrežo lahko opišemo kot skupno delo akterjev, ki imajo enake ali podobne cilje, niso povezani $\mathrm{v}$ hierarhičen sistem in delujejo na podlagi zaupanja. V mreži podjetij sodelujejo izključno gospodarski subjekti, ki so povezani zato, ker od tega pričakujejo formalno ali neformalno izmenjavo različnih vsebin. To prinaša materialne ali nematerialne dobičke bodisi mreži kot celoti bodisi posameznemu podjetju. Pri tem so podvrženi skupnemu sodelovanju in tudi medsebojni konkurenci (Bergman 2003). V grozdih se združujejo skupine povezanih podjetij ter institucij, ki so pomembne za proizvodnjo določene skupine izdelkov. Grozdi nudijo svojim članom konkurenčne prednosti, saj z rivalstvom in konkurenco med lokalnimi podjetji ter s prostorsko bližino lahko nastajajo proizvodne in procesne inovacije, prav tako pa lahko naraste tudi produktivnost faktorjev (Jarke in sodelavci 2003). Obenem mora biti mreža tesno vpeta v družbeno-kulturno okolje regije, njene informacijske lovke pa so lahko veliko širše razpredene, kar jim omogoča hiter razvoj informacijskih tehnologij.

Za inovacije je značilno, da so te bolj kot s t. i. footloose multinacionalnimi korporacijami povezane z visokotehnološkimi (angl.: high-tech) inovativnimi regionalnimi grozdi, s čemer naraste pomen geografske bližine in regionalnih aglomeracij (Audretsch 2003). Vendar pa za grozde ni pomembna le prostorska bližina, temveč so osrednjega pomena družbenoekonomski dejavniki. Gospodarsko ravnanje je tesno povezano s socialnim ravnanjem, pri katerem je izrednega pomena družbeni kapital (Jarke in sodelavci 2003). Pri tem mora mestni management težiti k vzpostavitvi vzvodov, ki bodo spodbujali k sodelovanju med podjetji, organizacijami in javnimi ustanovami, ter na ta način vzpostavljali okvir za reševanje skupnih problemov in krepili skupne učne procese (Diez 2001). Po načelih endogenega razvoja je v dobi globalizacije ter znanstveno-intenzivnega kapitalizma ravno regija ključno središče za učenje in ustvarjanje znanja, ter s tem tudi poglavitni vir inovacij in gospodarske rasti. (Diez in Esteban 2000).

Če je inovacijska mreža obenem vpeta še v regionalno okolje, govorimo o ustvarjalnem okolju (Chancen 1996). Ta temelji na netržni povezanosti med podjetji, ki obsega lokalno znanje in medosebni stik, formalne in neformalne mreže, kakovost lokalnih in regionalnih institucij ter njihovo tesno medseboj- 
no povezanost, pa tudi dolgotrajne navade in norme, s čemer ustvarjajo specifične prednosti in dobičke podjetjem in regiji. Tekmovalnost se pri tem osredotoča na družbeni kapital, kulturni kontekst, norme in vrednote, ki lahko spodbujajo medsebojno razumevanje in krepijo zaupanje med akterji regionalnega gospodarstva (Diez in Esteban 2000). Pri ustvarjalnem okolju je predvsem pomembno, da partnerji obdržijo svojo samostojnost, s svoje povezanosti pa črpajo impulze za hitrejši razvoj in razvijanje novih inovacij in tehnologij. Omrežja tako temeljijo na nematerialnih elementih, kot so zaupanje, latentno znanje, in skupna zavest vrednot. Na ta način lahko pride do pozitivnih učinkov miljeja, vključno z zmanjšanjem negotovosti pri odločitvah in učinkov skupnega učnega procesa, ki lahko vodi v nastanek specifičnega regionalnega know-howa (Maier in Obermaier 1999). Za ustvarjalna okolja je značilno, da nastanejo na območjih prebivalstvene in gospodarske aglomeracije, saj so v tesni odvisnosti od kritične mase raziskovalcev, ki predstavlja približno $10 \%$ prebivalstva. Zato je zelo zaželen obstoj univerzitetne ali visokošolske institucije, ki skrbi za prenos znanja. Pomen visokošolskih in raziskovalnih organizacij se je v zadnjem času močno povečal. V okviru inovacijske konkurenčnosti igra inovacijski potencial zelo pomembno vlogo, iz katere izhajajo impulzi rasti za nadaljnji regionalni razvoj. Visoke šole povečujejo inovacijski potencial in zvišujejo človeški kapital, s tem pa tudi prednost nekega območja v regionalni konkurenci. Na ta način so visoke šole inkubatorji znanja in motivatorji razvoja obenem (Heeb 2003). Visoke šole morajo tudi vdihniti podjetniški duh njihovim diplomantom, saj dosedanja praksa kaže, da se le manjši del diplomantov odloči za samostojno podjetniško pot takoj po diplomi, večinoma pa se za samostojno pot odločijo šele čez 8-15 let, ko si pridobijo že nekaj izkušenj (Jarke in sodelavci 2003).

Za uspeh ustanovitve visoko tehnološko usmerjenih podjetij, je ključnega pomena visok potencial rasti in podpora tovrstnih podjetij s strani domačega inštituta oziroma s tem povezanega znanstveno-industrijskega omrežja. To omrežje omogoči zmanjšanje potreb po kapitalu, s čemer se ustanovitev v številnih primerih sploh omogoči. Omrežje omogoča tudi nadaljnjo rast teh podjetij in zmanjšuje obstoječa tveganja. Na ta način se lahko zmanjšata poglavitni oviri pri ustanavljanju novih podjetij, to sta kapital in marketing, saj lahko oba začasno nadomestimo z omrežjem (Burkhardt in sodelavci 2003). Inovacije in tehnologija so v devetdesetih letih 20. stoletja veljale za rešilno strategijo, saj pripomorejo k skrajšanju produkcijskega cikla, zagotavljajo intenzivno interakcijo med znanostjo, tehniko in gospodarstvom ter dajejo odgovor na naraščajočo kompleksnost tehnologij, ter naraščajočo konkurenco na podlagi internacionalizacije in globalizacije. Inovativne regije morajo danes iskati nove tehnologije in know-how ter $\mathrm{z}$ razvojem specifičnih rešitev spet ustvariti nove tržne ponudbe (Gerhardter in Gruber 2001).

Vendar pa na ustvarjalna okolja ne moremo gledati zgolj kot na inovativna omrežja usmerjena v tehnologijo, temveč bolj v smislu sposobnosti regionalnih akterjev, da se povežejo z raziskovalnimi ustanovami zaradi razvoja obstoječih potencialov (Maier in Obermaier 1999). Endogenost lahko na ta način pomeni sposobnost regionalnih akterjev, samostojno sprejeti eksterne informacije (know-how, tehnologije, organizacijske strukture) in jih vgraditi v lastni regionalni sistem. Pri tem za uspešnost regionalnega razvoja niso odločilne le posamezne iniciative, temveč usklajeno delovanje vseh razvojnih dejavnikov (Gerhardter in Gruber 2001). S tega vidika ima pomembno vlogo regionalno podporno okolje, ki se pojavlja med "produkcijskim « in »tržnim « okoljem. Predstavlja odnose, ki glede na produkcijske faktorje ne spadajo med normalne tržne odnose, so pa ključnega pomena pri delovanju podjetij (izmenjava informacij, sodelovanje, strateške povezave). Podporno okolje je še zlasti pomembno za mala in srednje velika podjetja, ki pogosto nimajo dostopa do virov, ki bi jim omogočili samostojno uvajanje inovacij. Razvoj podpornega okolja ni samoumeven, saj obstajajo zanj trije pomembni pogoji - posebna ekonomska struktura (velikost in vrsta oziroma panoga), pozitivni lokacijski dejavniki (infrastruktura, kakovost življenja) ter sinergijski učinki (raziskovalne ustanove, rizični kapital, razpoložljiva delovna sila) (Maier in Obermaier 1999).

Po podatkih Svetovne banke imajo v strukturi celotnega kapitala, definiranega kot proizvodni kapital, največji delež človeški kapital (64\%), naravna bogastva (20\%) in finančni kapital (16\%) (Lorber 2002). Pri tem moramo človeški kapital nujno jemati širše, kot družbeni kapital, saj le-ta vpliva na številne proizvodne procese. Bourdieuju pomeni "... agregat dejanskih ali potencialnih resursov, ki sledijo iz trajne mreže bolj ali manj institucionaliziranih odnosov, medsebojnih poznanstev ali socialnega ugleda ... «. Podobno ga pojmuje tudi Putnam (1995, citirano po: Jarke in sodelavci 2003), ki ga opredeli kot »... lastnosti socialne organizacije, kot so mreže, norme in zaupanje, ki lajšajo kooperacijo ter stem prinašajo obojestransko korist ..." 
Skupen uspeh posameznih akterjev v neki regionalni ekonomiji ne pomeni le trajnejšega uspeha neke regije, temveč vzpodbuja tudi nove podjetnike, da v tem grozdu začnejo s svojo dejavnostjo (Szyperski 2003). Vendar pa je za razvoj tovrstnih območij zelo pomemben kapital, predvsem rizičen - venture kapital, ki se je razvil skupaj s tehnološko in podjetniško bazo v tesni navezavi na inovativna okolja.

Znanje postaja poglavitni lokacijski dejavnik in povzroča velike spremembe v regiji sami. Surovine, delovna sila in zemljišče niso več odločujoči, odločilna postaja prostorska koncentracija sorodnih dejavnosti in ustvarjanje znanja (družbeni kapital). To ima posledice tudi v mestni regiji: delitev dela ni več tako enoznačna, pojavijo se številni novi profili za delovna mesta, potrebne so nove veščine, saj morajo delavci opravljati več bolj raznovrstnih del. Nastajanje grozdov je značilno za praktično vse dejavnosti, kjer je znanje odločujočega pomena: biotehnologija, računalništvo in informatika, medijska industrija, avtomobilska industrija. Obenem poteka povezovanje podjetij z znanstvenimi institucijami, ki se specializirajo in nadgrajujejo na podoben način (univerzitetni centri, tehnološki parki, sejmi).

\section{Součinkovanje raziskovanja, sodelovanja in konkurenčnosti mest/regij - primer Ljubljane}

Sodelovanje mest/regij in konkurenčnost oziroma tekmovalnost sta dve plati iste medalje. To je v primerih majhnih mest, kakršna so $\mathrm{v}$ Sloveniji, $\mathrm{z}$ razvojnega vidika še posebej pomembno. Poleg prizadevanj po sodelovanju so v razmerah globalizacije vedno bolj pogostejše tudi ideje po tekmovalnosti: »... Obstoj tekmovalnosti na vseh ravneh - tudi med partnerji znotraj vodilne in enotne mestne regije - postaja $v$ sodobnosti dejstvo ... (Sturm 2000). Pod pritiski uravnotežene tekmovalnosti raste pomen sodelovanja. Presečne povezave med sodelovanjem in tekmovalnostjo mest so tesne pri čemer jim je skupni imenovalec ustvarjalnost. Pri sodelovanju gre dodatno le še za razširitev stremljenj in za razširitev sodelovanja, kakršno ponuja tekmovalnost med mesti. Konkurenca je torej odločujoči dejavnik za regionalno kooperacijo znotraj in med mestnimi regijami (Bergmann in Jakubowski 2001).

Konkurenčnost mest ni cilj, temveč pospešuje medsebojno sodelovanje v skupno korist dveh ali večih partnerskih mest. Pomeni decentralizirano koordinacijo individualnih aktivnosti. Poleg tega v okvirih kooperativnega samouravnavanja v celotni družbeni skupnosti (regiji) in še posebej v mestih sistematično pospešuje celokupni družbeni razvoj.

Konkurenčnost je običajno kot princip uravnavanja trga razpoznavna kot prizadevanje za večjo kakovost ali nižjo ceno storitev med udeleženci na trgu. Tržni alokacijski mehanizmi v sodobnosti podpirajo tudi decentralizacijske strukture, poleg tega pa ekonomska ravnanja akterjev izhajajo iz maksimizacijskih načel dobička in nasprotujejo vsebinskim normiranjem, značilnim za prostorsko planiranje. Uravnotežena konkurenčnost med mestnimi regijami pa po drugi strani povečuje učinkovitost in oživlja optimalne vložke glede na razpoložljiva sredstva. Iz naslednjih razlogov lahko pričakujemo pozitivne rezultate. Najprej gre za pozitivno sporočilo vsem lokalnim in regionalnim akterjem, da morajo svoje konkretne aktivnosti še izboljšati in njihove koncepte, organizacijske oblike in ukrepe še nadalje razvijati, kar v končni fazi pomeni selekcijo. Institucionalizacija konkurenčnosti je izziv za pospeševanje učinkovitosti tudi med družbenopolitičnimi skupnostmi, za zniževanje stroškov ob zviševanju kakovosti ponudbe, in to ne le v statičnem pomenu, ampak predvsem z vidika dinamične perspektive. Odkriva nove možnosti za inovativne procese. Kot uspeh je pričakovati močnejšo prilagodljivost in mobilnost lokacijskih dejavnikov v konkretnem okolju. »... Pozitivne posledice tekmovanja mest so v končni obliki: neprekinjeno izboljševanje temeljev gospodarskega ravnanja in izboljšana skladnost pričakovanj državljanov in podjetij z delovanjem uprave. Na ta način se poveča učinkovitost pri alokaciji dejavnosti, dinamična je prilagoditev in zagotavljanje ekonomskih učinkov ... (Götz 1998). Okvirne pogoje medsebojne povezanosti in učinkovitost uravnotežene konkurenčnosti prikazuje slika 1 .

Prostorske učinke zgornjih aktivnosti lahko razložimo s smermi, intenzivnostjo ter izhodiščnimi in končnimi blagovnimi ter prebivalstvenimi migracijskimi tokovi. Z gospodarskega vidika vodi konkurenčnost $\mathrm{v}$ (tudi neformalno) institucionalizacijo gospodarnejših in mobilnih dejavnikov, pri čemer ima izbor oziroma 


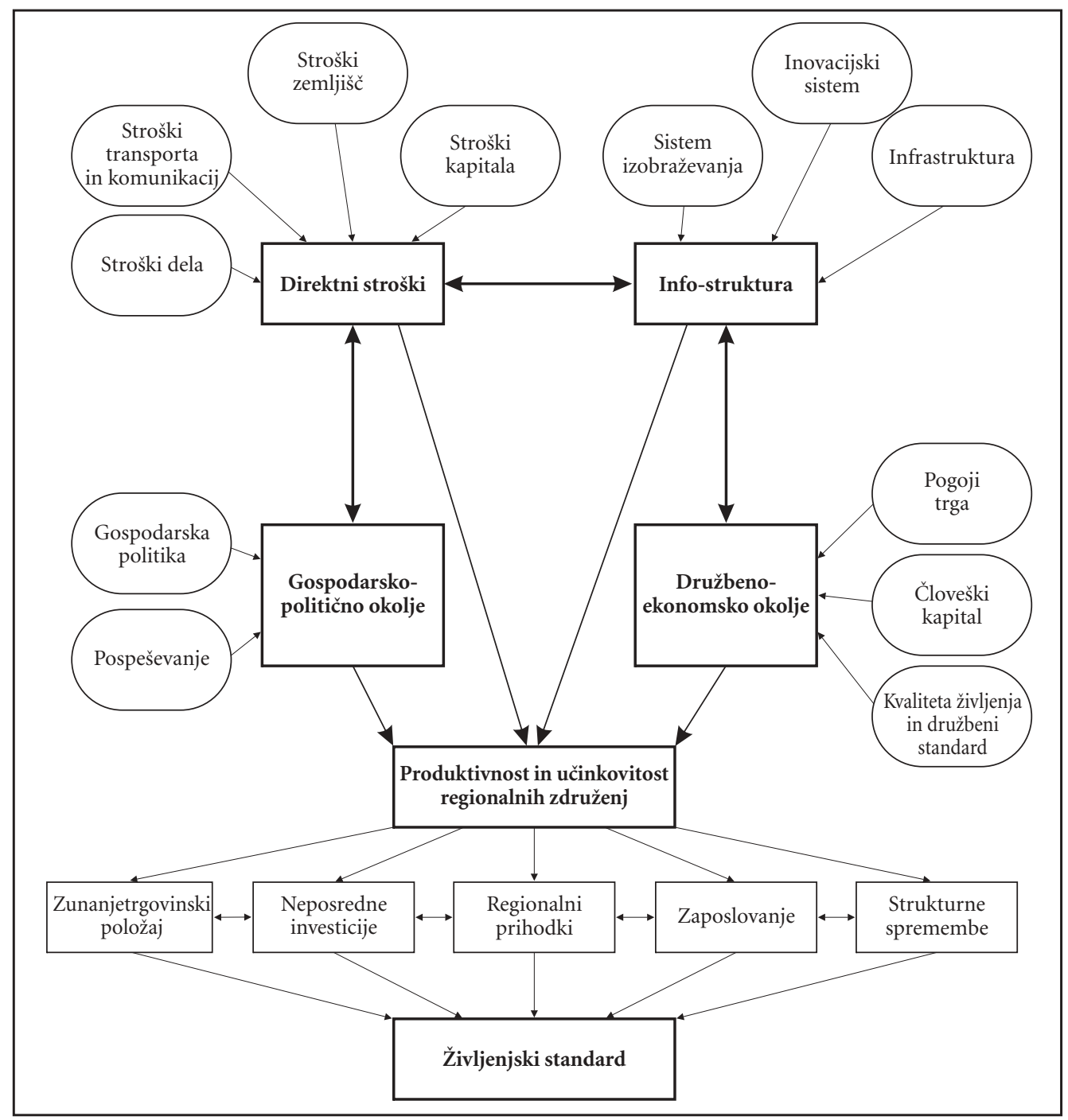

Slika 1: Temeljne značilnosti uravnotežene konkurenčnosti mest/regij (prirejeno po: Mayerhofer 1998).

selekcija (sodobnih) lokacijskih dejavnikov pomembno vlogo (med katerimi imajo vidni učinek npr. selitve podjetij in prebivalcev na suburbanizirano obrobje mest).

Slovenski urbani sistem je v evropskih merilih relativno nerazpoznaven saj ima le ljubljanska mestna regija več kot pol milijona prebivalcev. Ob milijonskih mestih (Dunaj, München, Budimpešta, Praga, Milan, Zagreb) je v bližnji soseščini v Srednji Evropi še vrsta mest $\mathrm{z}$ univerzitetno in raziskovalno tradicijo, ki štejejo 100.000-400.000 prebivalcev in so med seboj malo oddaljena ter (z izjemo italijanskih mest) ležijo $\mathrm{v}$ srednje velikih državah. $\mathrm{V}$ omrežju mest je v naslednjih desetletjih mogoče pričakovati korenite spremembe $\mathrm{v}$ prostorskih razmerjih, kjer bodo srednje velika in tudi velika mesta iskala svoje kooperacijske partnerje. Čezmejno sodelovanje je zagotovo ena od enkratnih priložnosti za preseganje šibkih razvojnih in raziskovalnih kapacitet mest. Ljubljansko (in s tem tudi slovensko) urbano omrežje na temeljih svojega geopolitičnega položaja (in spodbujenega zaradi bližine zunanje EU meje) vse bolj postaja del globalizacijskih tokov, ki s pomočjo produkcijskih in služnostnih dejavnosti dobiva vse bolj nadna- 
cionalen značaj. Pri tem igra posebno vlogo prav omrežje treh univerzitetnih središč ob petem evropskem razvojnem koridorju.

V Ljubljani je sedež vseh ministrstev in večine vladnih služb. Zato mesto privablja številne komplementarne dejavnosti, ki so tesno povezane z javno upravo. Je tudi najprimernejše središče za umeščanje sedežev podjetij, saj bližina upravnih organov omogoča pretok informacij med podjetji in državnimi institucijami. Kot glavno mesto s središčnim položajem je Ljubljana deležna številnih ugodnosti, ki povišujejo njeno lokacijsko privlačnost in povečuje lokacijsko rento. Ker se v javni upravi in podjetjih z visoko dodano vrednostjo zaposluje pretežno bolj izobražena delovna sila, ki je tudi bolje plačana, se to pozna pri prihodkih mesta. Leta 2003 je povprečna bruto plača v Ljubljani za 23,5\% presegala povprečno bruto plača v Sloveniji. V Ljubljani je močno nadpovprečna tudi bruto osnova za dohodnino na prebivalca, ki presega državno povprečje za 38,9\%. Slednje se ugodno kaže v relativno visokih prilivih v mestno blagajno, saj je dohodnina eden poglavitnih virov financiranja slovenskih občin. Naslednja prednost delovnih mest $v$ javni upravi je tudi njihova relativna stabilnost in gotovost. Kot močno zaposlitveno središče je Ljubljana že dalj časa privabljala prebivalstvo iz celotne države - tudi z obrobnih območij Slovenije, pri tem pa se v mestu zaposlujejo bolje izobraženi prebivalci. Nadalje se z zgoščevanjem prebivalstva zmanjšujejo stroški javnih storitev na prebivalca, povečujejo pa pritiski na okolje, kar lahko vodi v nastanek disekonomije, oz. negativnih učinkov, ki jih prinaša zgoščevanje prebivalstva.

Zaradi centralnosti je Ljubljana deležna obsežnih državnih sredstev, pri čemer izstopajo sredstva v zdravstvo, oskrbo, kulturo in izobraževanje. Na področju kulture dobi Osrednjeslovenska statistična regija blizu $45 \%$ posrednih regionalnih spodbud, pri čemer poglavitni delež odpade na samo mesto. Prav tako izstopa pri sredstvih, namenjenih izobraževanju (33\%), informacijski družbi $(28 \%)$ in zdravstvu (50\%). Omenjena področja so v razvojnem smislu pomembna, saj v večini primerov dvigujejo življenjsko raven prebivalstva, ki je v konceptu endogenega regionalnega razvoja eden ključnih dejavnikov privlačnosti mesta in regije. Na ta način se dviga kakovost tako imenovanih mehkih lokacijskih dejavnikov, kot so družbeni kapital, privlačnost prostora $\mathrm{z}$ vidika kulturne ponudbe ter $\mathrm{z}$ vidika celovite oskrbe.

Ljubljana je največje univerzitetno središče v državi po številu raziskovalcev in profesorjev ter po številu študentov. V njej je 200 raziskovalnih organizacij, kar je $42 \%$ vseh raziskovalnih organizacij v državi in zaposluje 6566 raziskovalcev, ali skoraj dve tretjini slovenskih raziskovalnih kapacitet. Univerza v Ljubljani s svojo razvejeno izobraževalno in raziskovalno ponudbo privlači večji del slovenskih študentov. Tako je bilo na Univerzi v Ljubljani v šolskem letu 2004/05 vpisanih 57.064 študentov, kar je $64 \%$ vseh študentov v Sloveniji. Še višji je njen delež pri diplomantih, ki znaša skoraj 70 \% (2003/04).

Slika 2: Diplomanti univerz in samostojnih visokih šol v letu 2003.

Glej angleški del prispevka.

Ljubljana izstopa tudi po deležu študentov v visokih strokovnih šolah. Te so v državi bolj razpršene, saj zanje veljajo ohlapnejše zahteve kot za fakultete, so pa kljub temu izredno pomembne, saj je njihov temeljni cilj tesna navezanost na gospodarstvo. $S$ tem naj bi te šole zagotavljale strokovnjake $z$ več praktičnimi izkušnjami, ki se bodo neposredno po zaključku študija sposobni spopasti z zahtevnimi problemi, ki se odpirajo v podjetjih njihove zaposlitve.

\section{Slika 3: Število vpisanih študentov v visoke šole v študijskem letu 2003/04.}

Glej angleški del prispevka.

Študentje, ki študirajo v Ljubljani, so za mestno gospodarstvo pomemben vir dohodka, saj plačujejo številne storitve, kot so bivališče, javni prevoz, prehrana, izobraževanje, kulturne in športne prireditve. Številne omenjene dejavnosti so subvencionirane tudi s strani države. Študentje, ki predstavljajo približno šestino mestnega prebivalstva, so pomemben segment potrošnje. Pomen študentov v mestnem gospodarstvu dodatno povečuje multiplikacijski učinek, saj ta vpliva tudi na povečanje zaposlovanja, tako na področju samega izobraževanja, kot tudi pri ostalih panogah. 
Mesto mora skrbeti za odpiranje novih, privlačnih in visoko kakovostnih delovnih mest, s čemer se dviguje kupna moč prebivalstva, obenem pa z njimi (p)ostaja magnet za bolje izobraženo prebivalstvo, na nacionalni in na nadnacionalni ravni. $V$ tej povezavi so izjemnega pomena tudi nove investicije, ki ustvarjajo nova delovna mesta. V letu 2004 je bilo v Sloveniji aktivnih 7850 investitorjev, skupna vsota investicij je znašala 760 milijard SIT. Ilustrativen je tudi delež plačil za investicije/prebivalca, ki je znašal 387 tisoč SIT. Daleč najvišji je bil v osrednji Sloveniji, kjer je za 1,82 krat presegal slovensko povprečje. Prostorska razporeditev plačil za investicije kaže na prvi pogled relativno visoko stopnjo razprostranjenosti po celotni državi, saj je bila najmanj ena investicija v 1276 naseljih ali v povprečju v vsakem petem $(21 \%)$. V večini naselij gre predvsem za izplačila za investicije manjših vrednosti. Vse največje investicije (nad 10 milijonov SIT) so bile osredotočene v 44 naseljih, katerih skupna vrednost je znašala skoraj 470 milijard SIT ali $87 \%$ vseh investicij v Sloveniji. Med njimi izstopa Ljubljana s skupno 1904 investicijami v skupni vrednosti 227 milijard SIT ali $42 \%$. Skupna vrednost plačil za investicije je bila v Ljubljani šestkrat višja od investicij v Mariboru. Tudi dejavnostna struktura je enakomerno zastopana s pozitivnimi odstopanji od povprečja $\mathrm{v}$ javnih investicijah in gospodarski infrastrukturi. Podrobnosti prikazujeta sliki 4 in 5.

Slika 4: Prostorska razporeditev investitorjev v letu 2004.

Glej angleški del prispevka.

Slika 5: Veliki investitorji v Sloveniji v letu 2004.

Glej angleški del prispevka.

\section{Sklep}

Visoko kakovostne investicije in z njimi povezana delovna mesta so ključna za razvoj mesta, saj le inovacije vodijo v sledenje ob konkurenci mednarodnega trga in ob naraščajoči globalizaciji. Inovacije bodisi pocenijo proizvodnjo bodisi postrežejo z novimi proizvodi, ki pomenijo enakovredno ponudbo drugim ponudnikom. Inovativna območja, stroka jih označuje kot industrijske distrikte, so se v številnih primerih izkazala za gonilno silo razvojnega preboja. Ta območja slonijo na tesni prostorski povezanosti podjetij s podobno proizvodno usmerjenostjo, kar podjetjem omogoča ozko specializacijo, prav tako se lahko zanesejo na bogato znanje, ki jim ga ponuja okolica. Pride do tesnega sodelovanja med podjetji, ki ga plemeniti izmenjava dobrin in sodelovanje, ki vodi v korist vseh partnerjev. Močna specializacija v neko panogo hitro privabi tudi ostale podporne institucije, ki so pomembne za delovanje proizvodnih podjetij, tako zaradi ozke specializacije teh podpornih institucij, kot tudi zaradi njihove prostorske bližine. Pri tem je ključen hiter pretok informacij, ki je v inovativnem okolju bistvenega pomena za razvoj proizvodov, iskanju tržnih niš in tržišč. Pri razvoju tovrstnih okolij igra veliko vlogo mestna oblast, ki mora skrbeti, da so upravni postopki čim hitrejši, nezahtevni in kakovostni. Ker je na primeru Ljubljane nesmotrno pričakovati, da bi se proizvodna dejavnost osredotočila le na eno panogo, relativno majhno ozemlje omogoča nastanek več tovrstnih podjetniških mrež, ki so lahko med seboj tesno prepletene. Zelo zaželeno je tudi sodelovanje raziskovalnih institucij in njihova tesna vpetost $v$ te mreže. Ce je to zagotovljeno, lahko govorimo o kreativnih ali inovativnih miljejih, ki poleg same proizvodne organizacije vključujejo tudi močno podporo socialnega okolja, administracije in raziskovalnih organizacij.

Pri tem je izjemnega pomena navezanost na območje, ki ga je možno doseči izključno ob zagotavljanju visokega življenjskega standarda, pestri kulturni ponudbi ter s številnimi dejavnostmi, ki nekemu območju dvigujejo privlačnost. Tu pridemo do ključnega problema Ljubljane. Zaradi močnih suburbanizacijskih teženj se je namreč veliko »njenih« delavcev naselilo v širši soseščini. Če hoče torej Ljubljana zagotavljati privlačno okolje in na podlagi tega večjo zainteresiranost okoliškega prebivalstva za razvoj in napredek, je bistvena koordinacija razvojnih aktivnosti na regionalni ravni, saj se bo na ta način zagotovila vključenost vseh prebivalcev, prav tako pa se bo le s tem povečala tudi možnost sinergijskih razvojnih učinkov. Nadaljnji razvoj Ljubljane bo možen le, če bo kupna moč prebivalstva, ki gravitira na Ljubljano, dovolj visoka.

Če želimo povečati pomen Ljubljane v sistemu nasproti bližnjim velemestnim aglomeracijam, je treba vzpodbujati njeno notranjo inovacijsko dinamiko, ker razpolaga z zadostnim in dovolj velikim razvojno raziskovalnim potencialom ter gospodarsko in populacijsko zmogljivostjo. Kljub temu mora razvijati svo- 
jo samostojnost in si tako dolgoročno zagotoviti inovacijske možnosti. Pomanjkljivosti se lahko spremenijo v prednosti, če se bo Ljubljana zavedala svojega posebnega odnosa na državni ravni in svoje primerjalne prednosti izkoristila za bodoči razvoj. Potrebno je vzpostaviti kooperacijske in odgovorne odnose med mesti v vplivnem zaledju, ki bi »podeželskim« občinam omogočili soudeležbo pri inovativnem potencialu in pri gospodarskem uspehu njihovega centra.

Oblikovanje uspešnega omrežja mest je najpomembnejši motiv za uspešno zadovoljevanje gospodarskih interesov in tudi za izvajanje skupnih nalog na nadlokalnih ravneh. Policentrični urbani sistem je poglavitni temelj za utrditev mrežnega povezovanja mest in izhaja iz načel zagotavljanja enakovrednih življenjskih in delovnih razmer za vse prebivalstvo na celotnem ozemlju države. To v primeru organizacije omrežja javnih institucij višjih ravni predstavlja ob današnji stopnji motorizacije približno polurno dostopnost. Policentrični urbani sistem je s tem protiutež obstoječim težnjam z dvojno strategijo »izravnalnega « mestnega življenja:

- $\mathrm{z}$ ohranitvijo in pospeševanjem visoko specializiranih delovnih mest $\mathrm{v}$ središčih nacionalnega pomena in pomeni prepletanje spektra gospodarskih dejavnosti s središči nižjega regionalnega pomena in partnerskih mest po svetu, kjer je odločilno oblikovanje medmestnega omrežja med sosednjimi (in tudi oddaljenimi) mesti podobne velikosti;

- z vzpostavljanjem in poglabljanjem gospodarskih kooperacij med mesti in tudi s pripadajočim podeželjem, kar je v obojestransko korist zaradi dopolnjevanja funkcij. To se doseže z vzpostavitvijo konkurenčne uravnoteženosti omrežja mest, kakršna so tudi srednjeevropska mesta v soseščini. Izhajajoč iz ciljev in zamisli o nadaljnjem razvoju trajnostno naravnane in uspešne zasnove omrežja naselij, ki zagovarjajo pravično porazdelitev človeških virov, učinkovito rabo družbenih resursov in omejevanje potrošnje naravnih virov, naselbinsko strukturo ob proizvodnem in ustvarjalnem okolju tvorijo še gospodarska in javna (družbena) infrastruktura ter oskrbne dejavnosti. Stopnja vpliva posameznega sklopa na usmerjanje temeljnih področij konkurenčnosti je glede na položaj in funkcije v omrežju naselij različna. Njihov pomen na modelni ravni in relativnih razmerjih velikosti kvadrata prikazuje spodnja slika.

Slika 6: Instrumentalni pomen posameznih dejavnostnih sklopov pri usmerjanju uravnotežene konkurenčnosti - primer Ljubljane.

\begin{tabular}{|c|c|c|c|c|}
\hline \multirow[t]{2}{*}{ stopnja centralnosti } & \multicolumn{4}{|c|}{$\begin{array}{l}\text { stopnja vpliva posameznega sklopa pri usmerjanju temeljnih področij konkurenčnosti, } \\
\text { glede na položaj in funkcije v omrežju naselij }\end{array}$} \\
\hline & naselbinska struktura & $\begin{array}{l}\text { gospodarska in javna } \\
\text { infrastruktura }\end{array}$ & oskrba in preskrba & $\begin{array}{l}\text { proizvodno in } \\
\text { ustvarjalno okolje }\end{array}$ \\
\hline $\begin{array}{l}\text { državno središče } \\
\text { (Ljubljana) }\end{array}$ & $\square$ & & $\square$ & \\
\hline $\begin{array}{l}\text { središče nacionalnega } \\
\text { pomena } \\
\text { (Kranj, Novo mesto) }\end{array}$ & 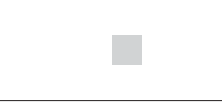 & & $\square$ & \\
\hline $\begin{array}{l}\text { središča regionalnega } \\
\text { pomena (Kamnik, } \\
\text { Domžale, Šk. Loka, } \\
\text { Vrhnika, Grosuplje) } \\
\end{array}$ & & & & 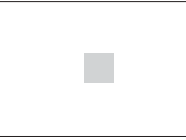 \\
\hline $\begin{array}{l}\text { središča lokalnega } \\
\text { pomena } \\
\text { (približno } 30 \text { naselij) }\end{array}$ & & $\square$ & & $\square$ \\
\hline
\end{tabular}

Nesporno je, da tudi iz Ljubljane ne glede na njeno majhnost, poleg njene gospodarske vloge izhajajo pomembni raziskovalni, kulturni in socialni impulzi. Za njen nadaljnji prostorski razvoj sta značilna dva nasprotujoča si procesa: demografska in naselbinska rast "navzven «s spreminjanjem pretežno kmetijskih zemljišč v mešano kmetijsko-urbano rabo in rast »navznoter « s spreminjanjem dohodkovno ekstenzivnejših rab v dohodkovno intenzivnejše. $V$ tržnih gospodarstvih se v mestnih središčih namreč ne morejo obdržati dejavnosti, ki na enoto površine ne ustvarijo dovolj dohodka za pokrivanje vseh stroškov, vključno 
z mestno rento. Na opuščenih (pretežno) industrijskih površinah v bližini mestnih središč nastajajo nova trgovsko-poslovna središča, ki z intenzivnejšo rabo zemljišč lahko pokrivajo porast urbanih stroškov. Neprofitne javne in upravne dejavnosti, ki v nasprotju s tržnimi zakonitostmi ostajajo na centralnih lokacijah, pa mora subvencionirati država, če jih želi obdržati na dostopnejših lokacijah.

\section{Literatura}

Glej angleški del prispevka. 